\title{
The Poopó Polymetallic Epithermal Deposit, Bolivia: Mineralogy, Genetic Constraints, and Distribution of Critical Elements
}

\author{
Belén Torres ${ }^{1}$, Joan-Carles Melgarejo ${ }^{1}{ }^{(}$, Lisard Torró ${ }^{2}\left(\mathbb{D}\right.$, Antoni Camprubí ${ }^{3, *}$, \\ Montgarri Castillo-Oliver ${ }^{4}$, David Artiaga ${ }^{5}$, Marc Campeny ${ }^{1,6}$, Esperança Tauler ${ }^{1}$, \\ Abigail Jiménez-Franco ${ }^{1,7,8}\left(\mathbb{0}\right.$, Pura Alfonso ${ }^{7}{ }^{-1}$ and Osvaldo R. Arce-Burgoa ${ }^{9}$ \\ 1 Departament de Mineralogia, Petrologia i Prospecció Geològica, Facultat de Ciències de la Terra, \\ Universitat de Barcelona, Carrer de Martí i Franquès s/n, 08028 Barcelona, Catalonia, Spain \\ 2 Geological Engineering Program, Faculty of Sciences and Engineering, Pontifical Catholic University of \\ Peru (PUCP), Av. Universitaria 180, San Miguel, Lima 15088, Peru \\ 3 Instituto de Geología, Universidad Nacional Autónoma de México, Ciudad Universitaria, \\ Coyoacán 04510 CDMX, Mexico \\ 4 Australian Research Council Centre of Excellence for Core to Crust Fluid Systems (CCFS) and GEMOC, \\ Department of Earth and Planetary Sciences, Macquarie University, North Ryde, NSW 2109, Australia \\ 5 Centres Científics i Tecnològics, Universitat de Barcelona, Carrer de Martí i Franquès s/n, 08028 Barcelona, \\ Catalonia, Spain \\ 6 Departament de Mineralogia, Museu de Ciències Naturals de Barcelona, Passeig Picasso s/n, \\ 08003 Barcelona, Catalonia, Spain \\ 7 Escola Tècnica Superior d'Enginyeria de Mines de Manresa, Universitat Politècnica de Catalunya, \\ Avinguda de les Bases de Manresa 61-73, 08242 Manresa, Catalonia, Spain \\ 8 Institut de Nanociència i Nanotecnologia (IN2UB), Facultat de Química, Universitat de Barcelona, \\ Avinguda Diagonal 645, 08028 Barcelona, Catalonia, Spain \\ 9 Colegio de Geólogos de Bolivia, Av. Hernando Siles entre calles 1 y 2, Zona de Obrajes, \\ Edificio Señor de la Exaltación Nro. 4683, La Paz 8941, Bolivia \\ * Correspondence: camprubitaga@gmail.com; Tel.: +52-55-56224310 (ext. 128)
}

Received: 19 June 2019; Accepted: 29 July 2019; Published: 31 July 2019

check for updates

\begin{abstract}
The tin-rich polymetallic epithermal deposit of Poopó, of plausible Late Miocene age, is part of the Bolivian Tin Belt. As an epithermal low sulfidation mineralisation, it represents a typological end-member within the "family" of Bolivian tin deposits. The emplacement of the mineralisation was controlled by the regional fault zone that constitutes the geological border between the Bolivian Altiplano and the Eastern Andes Cordillera. In addition to Sn and Ag, its economic interest resides in its potential in critical elements as In, Ga and Ge. This paper provides the first systematic characterisation of the complex mineralogy and mineral chemistry of the Poopó deposit with the twofold aim of identifying the mineral carriers of critical elements and endeavouring to ascertain plausible metallogenic processes for the formation of this deposit, by means of a multi-methodological approach. The poor development of hydrothermal alteration assemblage, the abundance of sulphosalts and the replacement of löllingite and pyrrhotite by arsenopyrite and pyrite, respectively, indicate that this deposit is ascribed to the low-sulphidation subtype of epithermal deposits, with excursions into higher states of sulphidation. Additionally, the occurrence of pyrophyllite and topaz has been interpreted as the result of discrete pulses of high-sulphidation magmatic fluids. The $\delta^{34} \mathrm{~S}_{\mathrm{VCDT}}$ range in sulphides ( -5.9 to $-2.8 \%$ o) is compatible either with: (i) hybrid sulphur sources (i.e., magmatic and sedimentary or metasedimentary); or (ii) a sole magmatic source involving magmas that derived from partial melting of sedimentary rocks or underwent crustal assimilation. In their overall contents in critical elements (In, Ga and Ge), the key minerals in the Poopó deposit, based on their abundance in the deposit and compositions, are rhodostannite, franckeite, cassiterite, stannite and, less importantly, teallite, sphalerite and jamesonite.
\end{abstract}


Keywords: critical elements; indium; gallium; germanium; tin; silver; low sulphidation; epithermal; Bolivian Tin Belt

\section{Introduction}

The Bolivian Andes include important resources in Sn and Ag, minor resources in base metals as $\mathrm{Cu}, \mathrm{Zn}$ and $\mathrm{Pb}$, and also in rare metals as $\mathrm{In}, \mathrm{Ge}$ or $\mathrm{Ga}$, and constitute the famous Bolivian Tin (Sn-W-Ag-Sb-Bi) Belt [1-5] (Figure 1). An increasing international demand is envisaged for In, Ge and $\mathrm{Ga}$, particularly in emerging technologies such as the production of photovoltaic cells (In and $\mathrm{Ga}$ ), optical fibre and infrared optical technologies (Ge). In addition, these metals are listed as Critical Raw Materials for the European Union [6], which attests to their strategic importance, particularly due to the large share in their supply by China-by far, the largest global producer of In, Ga and Ge in the present time. Consequently, special attention is needed in the mineral characterisation of the raw materials that carry In, Ga and Ge in the types of ore deposits that are susceptible of harbouring important resources in such metals.

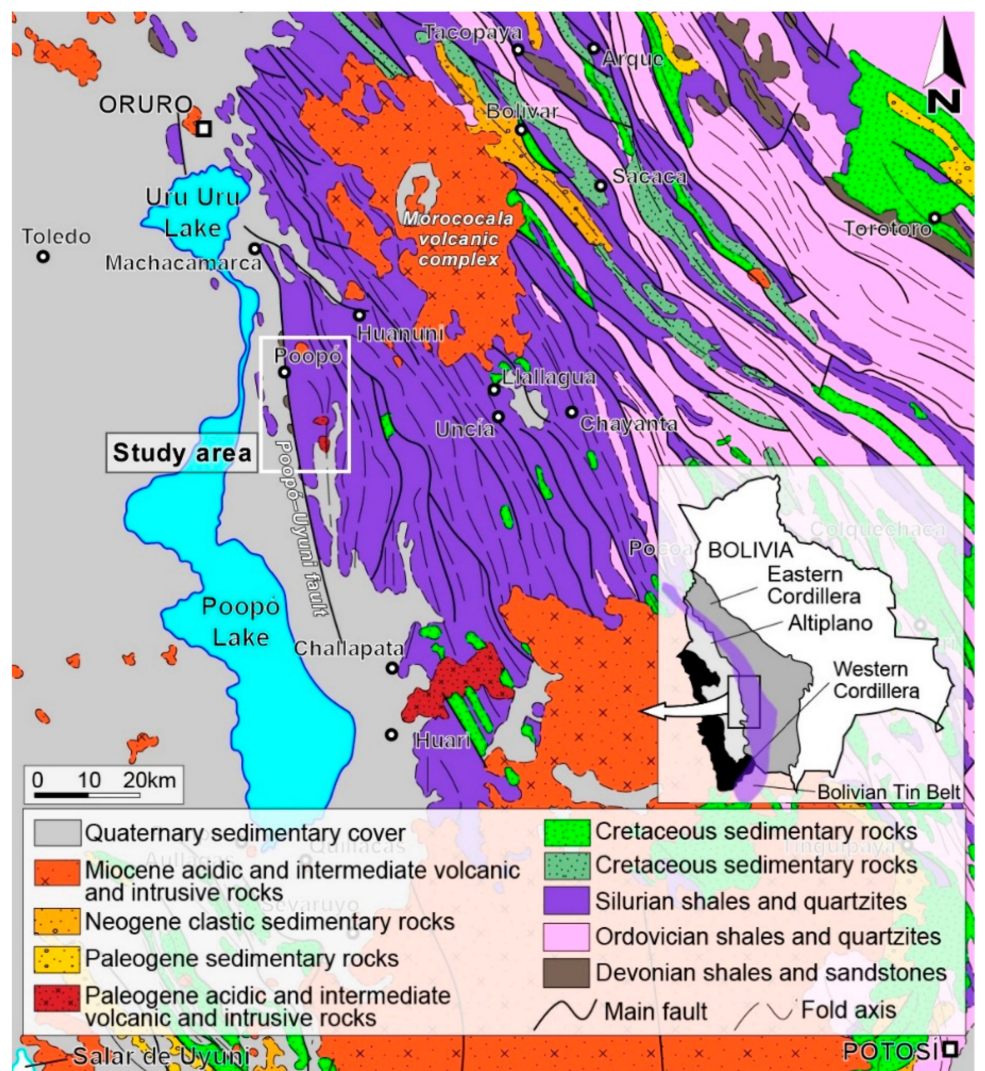

Figure 1. Regional geological map around the study area, adapted from Reference [7]. The distribution of the Bolivian Tin Belt was obtained from Reference [2].

In the particular case of Bolivia, the organisation of most mining activities is twofold: it is either carried out by cooperative organisations grouped into the National Federation of Mining Cooperatives of Bolivia (FENCOMIN) and that operate by means of traditional and non-industrial methods, or by the government itself by means of the Bolivian Mining Corporation (COMIBOL), although private corporations also operate in the country. This complexity in the management of mining activities in Bolivia results in strong differences in exploitation and exploration strategies and their efficiency between different mines, let alone the metallurgical processes involved. A critical aspect in which these activities are in need of assistance is the characterisation of ore bodies, their mineralogy and 
mineral chemistry or elemental distribution, particularly in the case of critical substances that can be considered as liabilities or "impurities" in the exploitation and metallurgy of tin or silver, instead of the subjects for major economic interest that they actually are. Therefore, mineralogical studies that address such issues are expected to raise awareness on the characteristics of raw material that is susceptible of mining and, consequently, to provide sound information to better guide the design of metallurgical processes that maximises the recovery of rare metals.

The Andes cordillera contains four great metallogenic belts. From west to east, these are the Fe, porphyry $\mathrm{Cu}-(\mathrm{Mo}-\mathrm{Au}), \mathrm{Cu}-\mathrm{Pb}-\mathrm{Zn}-\mathrm{Ag}$, and $\mathrm{Sn}-(\mathrm{W}-\mathrm{Ag}-\mathrm{Sb}-\mathrm{Bi})$ belts [3]. The Tin Belt extends between southeast Peru and the northernmost tip of Argentina, and most of it sits in western Bolivia (Figure 1). The Oruro region in southwest Bolivia sits on the central part of the Tin Belt, at the hinge between the northerly NW-SE part of the belt and the southerly N-S part (Figure 1). This region contains some of the most outstanding tin deposits in the world, which correspond to various types or models of formation. Among the relatively shallow types of Bolivian deposits, the Poopó deposit was labelled as a tin-rich low-sulphidation epithermal deposit [8]. Therefore, this deposit can be considered as one of the representative end-members in the "family" of Bolivian tin deposits. The aim of this paper is to provide a framework that summarises the mineralogical characteristics and the distribution of rare metals in this type of deposits. This is a second contribution among a group of papers related to various Bolivian tin deposits with the same collective aim.

\section{Geology}

The Poopó deposits are located north and south of the eponymous village, in the Oruro department, southwest Bolivia. The geographic coordinates of the spot in which the Poopó river crosses approximately midway of the mineralised structures in this location are -18.381579 and -66.957755 . The Poopó deposits are located near the border between the Bolivian Altiplano and the Eastern Andes Cordillera, by the NNW-SSE striking Poopó regional fault (Figure 1) and its associated structures [9]. Although no specific studies are available on this subject, it is possible that such a structure is part of a major crustal discontinuity or a cryptic structural corridor that favoured the emplacement of magmas and ore deposits as major channelways, similar to other regions in the world in different epochs [10-13]. This fault zone indeed coincides with a major crustal block or domain limit [14-19].

The Eastern Andes Cordillera (EAC) consists of Paleozoic low-grade metasedimentary rocks (slates, marls, sandstones, shales and quartzites) that were deposited in a broad marine basin. These were affected during the Miocene by several granitic intrusions with associated ignimbrites. The rocks of the EAC in the study area are essentially Silurian black shales and sandstones (Figure 1). The Bolivian Altiplano is a continental foreland basin between the Eastern and the Western Cordilleras that consists of Cenozoic sedimentary rocks, among which Pleistocene lacustrine deposits, great endorheic systems with salt flats, and volcano-plutonic complexes associated with the Andean orogeny [20] are noticeable. The Andean orogeny produced large-scale faults and fold-thrust belts with double vergence, although the east vergence is dominant [14-19]. The formation of ore deposits in the region is associated with the Andean orogeny and the concomitant magmatic activity.

The Poopó deposits consist of a vein system along the regional Poopó-Uyuni fault system with a general N-S strike (Figures 1 and 2). The largest vein in the area developed directly on the main fault, dips $50-70^{\circ} \mathrm{E}$, and experienced severe cataclastic deformation due to the fault reactivation after mineralisation. Ancillary veins around the main one show the same essential strike but milder deformation and less vertical dipping. The mineralogy of veins is ever dominated by quartz. Most veins show cataclastic brecciation that was associated with faulting activity, and breccia fragments were cemented by later hydrothermal mineralisation. Brecciation can also be due to hydrothermal processes alone, but it is a less common feature than cataclastic brecciation in these deposits. Whether brecciated or not, all veins show a polyphase and multi-episodic character typical of epithermal deposits. Neogene intermediate to acid volcanic domes occur in the vicinities of the veins, particularly close to them in the northern part of the vein system, between the Cóndor Iquiña and Calaveras areas (Figure 2). Such 
nearness has led to the suggestion that the formation of the veins was triggered by the emplacement of such domes [1].

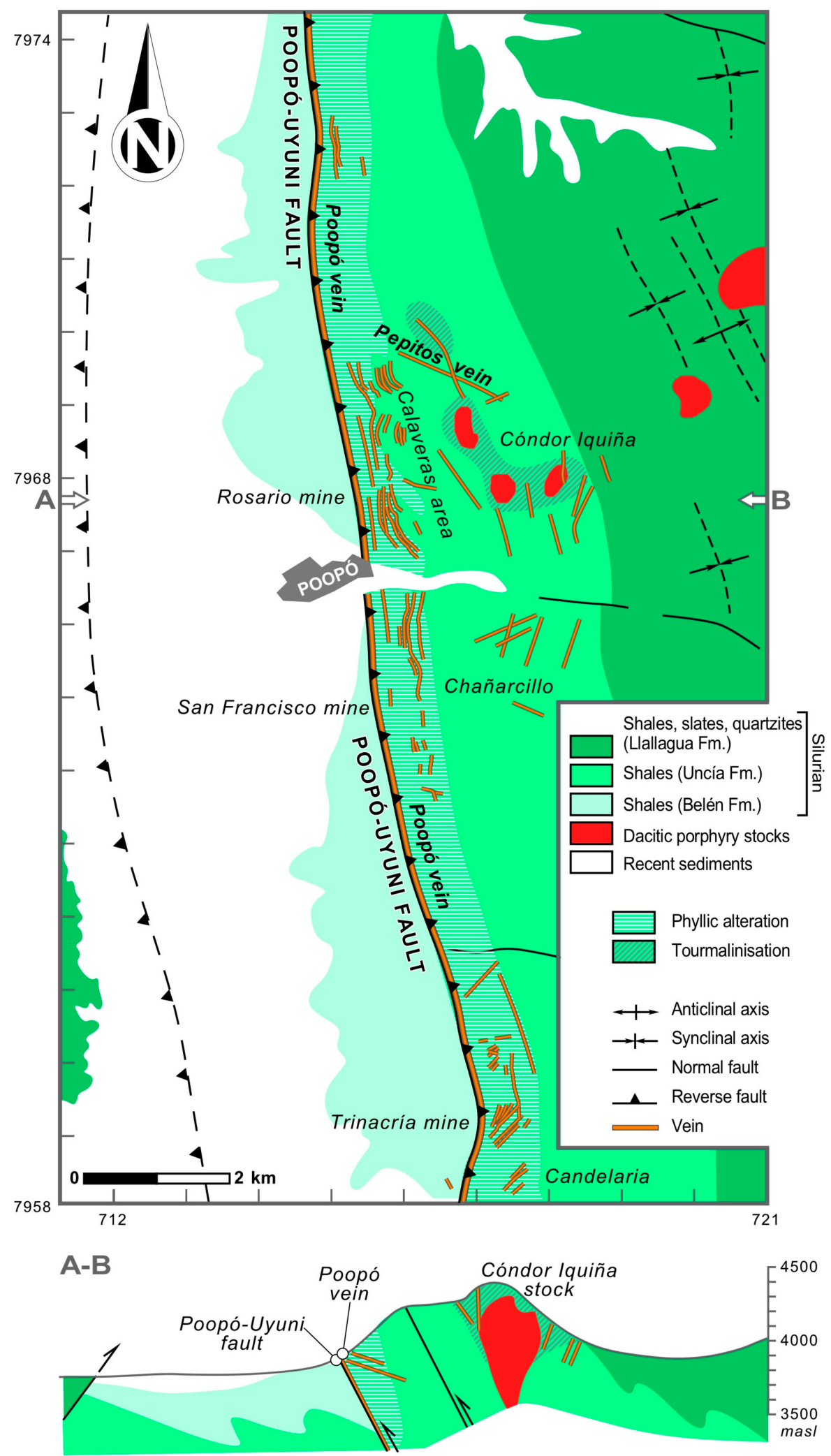

Figure 2. Local geological map of the Poopó area, redrawn from Reference [21]. 


\section{Methodology}

Two sets of mineralised structures were sampled, north and south of the Poopó village. These are mined by two cooperative entities: the Poopó Cooperative (north) and the San Francisco Cooperative (south), and were sampled on surface and underground exposures, respectively. The obtained samples were studied in thin and polished sections by means of transmitted- and reflected-light petrography, $X$-ray diffraction (XRD), scanning electron microscopy with energy analyser (SEM-EDS), electron probe microanalysis (EPMA), and laser ablation inductively coupled plasma mass spectrometry (LA-ICP-MS). With the sole exception of ICP-MS, all the equipment is available at the Centres Científics i Tecnologics of the Universitat de Barcelona.

The XRD equipment was a PANalytical XPert PRO MPD alpha1 diffractometre with a focaliser primary monochromator and an Xcelerator detector. The radiation used was $\mathrm{K} \alpha_{1} \mathrm{Cu}(\lambda=1.5406 \AA)$ at $45 \mathrm{kV}$ and $40 \mathrm{~mA}$. Spectra were interpreted by means of the PANalytical XPert software.

The SEM-EDS equipment was an ESEM Quanta 200 FEI XTE 325/D8395 electron microscope. A Zeiss Evo microscope with an EDS Oxford INCA detector, available at the Universitat Autònoma de Barcelona, was also used. Both microscopes were used at $20-25 \mathrm{keV}$ and at a working distance of $10 \mathrm{~mm}$.

EPMA analyses were carried out with a Cameca SX-50 with four WDS spectrometers and EDS at $20 \mathrm{keV}$ and beam current of $15 \mathrm{nA}$. The analytical programs and standards were pyrite (S, PET, K $\alpha)$, $\mathrm{FeS}_{2}(\mathrm{Fe}, \mathrm{LIF}, \mathrm{K} \alpha), \mathrm{Co}(\mathrm{Co}, \mathrm{LIF}, \mathrm{K} \alpha), \mathrm{NiO}(\mathrm{Ni}, \mathrm{LIF}, K \alpha)$, GaAs (As, TAP, $\left.L \beta\right)$, and InSb (Sb, PET, L $\beta$ ) for analyses on arsenopyrite; rutile (Ti, PET, $K \alpha), \mathrm{Fe}_{2} \mathrm{O}_{3}$ (Fe, LIF, $K \alpha$ ), $\mathrm{Nb}(\mathrm{Nb}, \mathrm{PET}, L \alpha)$, InSb (In, PET, $L \alpha$ ), cassiterite (Sn, PET, $L \alpha$ ), and Ta (Ta, LIF, $L \alpha$ ) for analyses on cassiterite; sphalerite (S, PET, K $\alpha$ ), $\mathrm{FeS}_{2}(\mathrm{Fe}$,

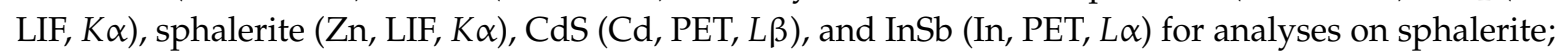

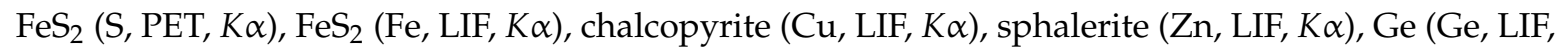
$K \alpha$ ), GaAs (As, TAP, $L \beta), \mathrm{Ag}_{2} \mathrm{~S}(\mathrm{Ag}, \mathrm{PET}, L \alpha)$, CdS (Cd, PET, $\left.L \beta\right)$, InSb (In, PET, $\left.L \alpha\right)$, cassiterite (Sn, PET, $L \alpha), \mathrm{InSb}(\mathrm{Sb}, \mathrm{PET}, L \beta), \mathrm{PbS}(\mathrm{Pb}, \mathrm{PET}, M \alpha)$, and $\mathrm{Bi}_{2} \mathrm{~S}_{3}(\mathrm{Bi}, \mathrm{LIF}, L \alpha)$ for analyses on sulphosalts. The detection limit (d.1.) for each element and the obtained data are displayed in Supplementary Materials Table S1.

LA-ICP-MS analyses were carried out with a Photon-Machines Excite $193 \mathrm{~nm}$ excimer laser system coupled to an Agilent $7700 \times$ ICP-MS mass spectrometer available at Macquarie University Geochemical Analysis Unit (GAU) (Australia). Calibration of the instrument was done using a NIST610 standard and the values of $\mathrm{Cu}$ and $\mathrm{Bi}$ [22]. Each analysis of cassiterite, rhodostannite, stannite and teallite was normalised to the Sn contents determined by the electron microprobe; whereas sphalerite analyses were normalised against $\mathrm{Zn}$. The counting time for each analysis was $90 \mathrm{~s}$, including $30 \mathrm{~s}$ of background and $60 \mathrm{~s}$ of sample acquisition. In all analysis, the repetition rate of the laser beam was $10 \mathrm{~Hz}$, and its energy density, $70 \%\left(6.5 \mathrm{~J} / \mathrm{cm}^{2}\right)$. To monitor the accuracy of the measurements, the BCR-2 (Basalt, Columbia River) standard was also analysed as secondary standard. The samples were analysed in runs of 15 analyses, comprising 10 analysis of unknowns, bracketed by two analyses of the NIST610 at the beginning and the end of each run, as well as one analysis of the BCR external standard after the first set of NIST610. The detection limits for REE, Ba, Rb, Th, U, Nb, Ta, Pb, Sr, Zr, Hf, Ti, Y and Ga span 10 to $20 \mathrm{ppb}$, for Sc and V $100 \mathrm{ppb}$, and for Ni 2 ppm. The accuracy for each analysis ranges between 1 $\mathrm{wt} . \%$ and $10 \mathrm{wt} . \%$, and the spot diameter ranged between 14 and $40 \mu \mathrm{m}$. Data reduction was carried out online by using the GLITTER software [23,24]. The data are displayed in Table 1 (selected elements In and Ga) and in Supplementary Materials Table S2 (full extent of analysed elements).

Sulphur isotopes analyses were analysed in 85 single grains of sulphide minerals. Pyrite, chalcopyrite, sphalerite and galena grains were separated by careful hand picking under a binocular microscope. Samples were analysed with a continuous flow mass spectrometer Delta C Finnigan MAT coupled with an elemental analyser TC-EA Carlo Erba 1108, at the Centres Científics i Tecnològics of the Universitat de Barcelona. The results are expressed in the delta notation as per mil deviations of the Vienna-Canyon Diablo Troilite (VCDT) standard and the standard deviation is determined to be 
$0.2 \%$. The results were calibrated by using the IAEA S1, IAEA S2, IAEA S3 and NBS-123 international reference standards, and are displayed in Table 2.

Table 1. In and Ga determinations by means of LA-ICP-MS in selected minerals of the Poopó deposit. All values are reported in ppm. Data selected from Table S2.

\begin{tabular}{|c|c|c|c|c|c|}
\hline Mineral & Label & ${ }^{115} \mathrm{In}$ & $1 \sigma$ & ${ }^{69} \mathrm{Ga}$ & $1 \sigma$ \\
\hline \multirow{26}{*}{ sphalerite } & P1-B-32 & 269 & 65 & 110 & 85 \\
\hline & P2-A-37 & 1030 & 180 & 140 & 35 \\
\hline & P2-B-40 & 2360 & 170 & 246 & 18 \\
\hline & P2-C-46 & 949 & 84 & 233 & 21 \\
\hline & P2-D-48 & 2520 & 80 & 340 & 11 \\
\hline & P3-A-49 & 10,500 & 340 & 1360 & 46 \\
\hline & P3-B-52 & 3640 & 110 & 717 & 22 \\
\hline & P3-B-53 & 5750 & 190 & 1280 & 45 \\
\hline & P4-A-67 & 1120 & 220 & 380 & 75 \\
\hline & P4-B-70 & 779 & 170 & 608 & 120 \\
\hline & P4-D-73 & 1850 & 390 & 565 & 120 \\
\hline & P4-E-75 & 5010 & 1200 & 599 & 140 \\
\hline & P5-A-77 & 3230 & 750 & 463 & 110 \\
\hline & P6-A-81 & 360 & 95 & 447 & 110 \\
\hline & P6-A-82 & 457 & 120 & 260 & 74 \\
\hline & P7-A-84 & 1610 & 110 & 166 & 12 \\
\hline & P7-B-86 & 1300 & 92 & 289 & 23 \\
\hline & P8-A-88 & 809 & 65 & 478 & 40 \\
\hline & P9-A-93 & 203 & 19 & 246 & 25 \\
\hline & P9-B-96 & 1850 & 190 & 769 & 85 \\
\hline & P9-B-97 & 307 & 34 & 266 & 31 \\
\hline & P10-A-147 & 269 & 73 & 164 & 46 \\
\hline & P10-B-149 & 1120 & 380 & 146 & 47 \\
\hline & P10-C-152 & 482 & 200 & 116 & 50 \\
\hline & P11-B-156 & 3870 & 1100 & $<\mathrm{dl}$ & - \\
\hline & P11-C-157 & 3780 & 1200 & 508 & 100 \\
\hline \multirow{8}{*}{ stannite } & P1-C-34 & 368 & 23 & 199 & 13 \\
\hline & P2-B-41 & 2400 & 200 & 85.7 & 7.1 \\
\hline & P2-D-47 & 3140 & 290 & 53.8 & 5.1 \\
\hline & P8-B-91 & 1090 & 94 & 0.90 & 0.094 \\
\hline & P9-A-94 & 2820 & 380 & 10.9 & 0.96 \\
\hline & P10-C-153 & 2650 & 1400 & 46.4 & 24 \\
\hline & P11-C-158 & 11,100 & 3200 & 38.9 & 13 \\
\hline & P11-D-159 & 8040 & 2400 & 22.9 & 6.5 \\
\hline \multirow{5}{*}{ rhodostannite } & P4-A-68 & 6070 & 1200 & 377 & 74 \\
\hline & P4-B-69 & 5160 & 1000 & 239 & 48 \\
\hline & P4-D-72 & 6030 & 1300 & 441 & 95 \\
\hline & P4-E-76 & 5800 & 1300 & 316 & 81 \\
\hline & P7-B-87 & 1240 & 260 & 241 & 10 \\
\hline \multirow{4}{*}{ teallite } & P5-B-80 & 10,800 & 2900 & 108 & 23 \\
\hline & P8-A-89 & 1480 & 120 & 54.0 & 6.0 \\
\hline & P8-A-90 & 1220 & 98 & 10.3 & 2.2 \\
\hline & P9-A-95 & 1460 & 150 & 0.76 & 0.096 \\
\hline \multirow{4}{*}{ cassiterite } & P1-B-33 & 3530 & 130 & 24.3 & 0.38 \\
\hline & P2-A-39 & 3070 & 110 & 8.95 & 1.4 \\
\hline & P2-B-42 & 4280 & 150 & 157 & 16 \\
\hline & P10-B-150 & 18,3000 & 1900 & 3060 & 306 \\
\hline
\end{tabular}

Key: <dl: below detection limits. -: no result. 
Table 2. Sulphur isotopic composition of sulphides in the Poopó deposit (Bolivia), normalised to the Vienna-CDT (VCDT) standard.

\begin{tabular}{|c|c|c|}
\hline Sample & Mineral & $\delta^{34} S_{\text {VCDT }}(\% o)$ \\
\hline P1 & chalcopyrite & -4.8 \\
\hline P6 & pyrite & -3.7 \\
\hline P7 & $\begin{array}{c}\text { pyrite } \\
\text { sphalerite }\end{array}$ & $\begin{array}{l}-3.4 \\
-2.8\end{array}$ \\
\hline P8 & $\begin{array}{c}\text { pyrite } \\
\text { sphalerite } \\
\text { chalcopyrite }\end{array}$ & $\begin{array}{l}-4.1 \\
-3.2 \\
-4.2\end{array}$ \\
\hline P11 & $\begin{array}{c}\text { pyrite } \\
\text { sphalerite }\end{array}$ & $\begin{array}{l}-4.2 \\
-5.8\end{array}$ \\
\hline P12 & $\begin{array}{c}\text { pyrite } \\
\text { sphalerite }\end{array}$ & $\begin{array}{l}-4.6 \\
-5.5\end{array}$ \\
\hline P13 & sphalerite & -5.4 \\
\hline P19 & $\begin{array}{l}\text { pyrite } \\
\text { galena }\end{array}$ & $\begin{array}{l}-4.5 \\
-5.9 \\
\end{array}$ \\
\hline P22 & $\begin{array}{c}\text { pyrite } \\
\text { sphalerite }\end{array}$ & $\begin{array}{l}-5.4 \\
-4.6 \\
\end{array}$ \\
\hline P23 & sphalerite & -4.4 \\
\hline
\end{tabular}

\section{Mineralogy}

\subsection{Alteration Assemblages}

The extent of hydrothermal alteration around the mineralised structures is very limited (up to a few $\mathrm{cm}$ ) and often obscured by late fault reactivations and the subsequent infiltration of meteoric water. The visible portion of hydrothermal alteration assemblages (no drill cores are available) consists essentially of "sericite", quartz, pyrite and pyrophyllite. "Sericite", due to its crystal sizes (less than $50 \mu \mathrm{m}$ wide), corresponds to illite or illite-smectite and makes up to $90 \%$ (modal abundance) of altered host rocks, and was previously mapped all along the Poopó-Uyuni fault [21]. Pyrophyllite, albeit localised, is a conspicuous mineral in these alteration assemblages and occurs as pervasive replacements of host rocks or in stringers as radial aggregates of up to $\sim 200 \mu \mathrm{m}$ long crystals in close association with pyrite, and postdates part of the ore associations (Figure $3 \mathrm{~A}-\mathrm{G}$ ). Adularia does not appear to be an abundant gangue mineral, and occurs as vein material (Figure $3 \mathrm{H}$ ).

\subsection{Mineralogy of the Veins}

The veins-both the major ones along the Poopó-Uyuni fault and ancillary structures-are basically constituted by quartz and sulphides of various types. The mineralisation is characterised by abundant cataclastic textures. However, quartz shows various primary hydrothermal textures, such as massive milky aggregates, and banded to comb aggregates, and sulphides may form micro-banding textures with rhythmic patterns (Figure 4D) but they occur normally as passive or reactive successions by cavity or fracture lining (Figure 4E,F, Figures 5-8). Three episodes of mineralisation have been clearly elucidated from the present state of mining operations. In this section, we describe the minerals found in ore associations within the veins and their interrelationships. 



Figure 3. Photomicrographs of diagnostic gangue minerals in the Poopó deposit. (A) Pyrophyllite stringers with pyrite, in pyritised host shales; polarised reflected light. (B) Same as A, but under transmitted light and crossed polars. (C) Vein material (sphalerite, quartz and pyrite) with later pyrophyllite and pyrite replacing sphalerite; polarised transmitted light. (D) Same as C, but crossed polars. (E) Sphalerite stringers in host rocks that underwent strong alteration by pyrophyllite, with an association of pyrophyllite and pyrite replacing sphalerite through the stringer rims; polarised transmitted light. (F) Same as E, but crossed polars. (G) Same as E and F, but under polarised reflected light. (H) Association of tin sulphosalts (franckeite and rhodostannite) and sphalerite, cut by a later association of fine-grained adularia and pyrite; polarised reflected light. 



Figure 4. Photomicrographs and back-scattered electron images of selected textural features in the Poopó deposit. (A,B) Microbrecciation in hydrothermal ore-bearing associations cemented by tin and silver sulphosalts of Stages 2 and 3; polarised reflected light. For the complete mineralogy of cementing $\mathrm{Sn}, \mathrm{Pb}$ and Ag sulfosalts, see Figure 9. (C) Detail of brecciated material cemented by Stage-2 sulphides and sulphosalts; notice the rounded fragments of earlier vein material; back-scattered electron image. (D) Cyclic micro-banding textures in ore associations of Stage 2; back-scattered electron image. (E) Arsenopyrite $\rightarrow$ pyrrhotite $\rightarrow$ pyrite $\rightarrow$ sphalerite + sulphosalts succession with the development of "bird's eyes" textures due to the replacement of pyrrhotite by pyrite and mascasite; all the sequence is reactive except for the precipitation of pyrrhotite on arsenopyrite; polarised reflected light. (F) Teallite and "sericite" in micro-cavities after the precipitation of pyrite and wurtzite (reactive); back-scattered electron image. 


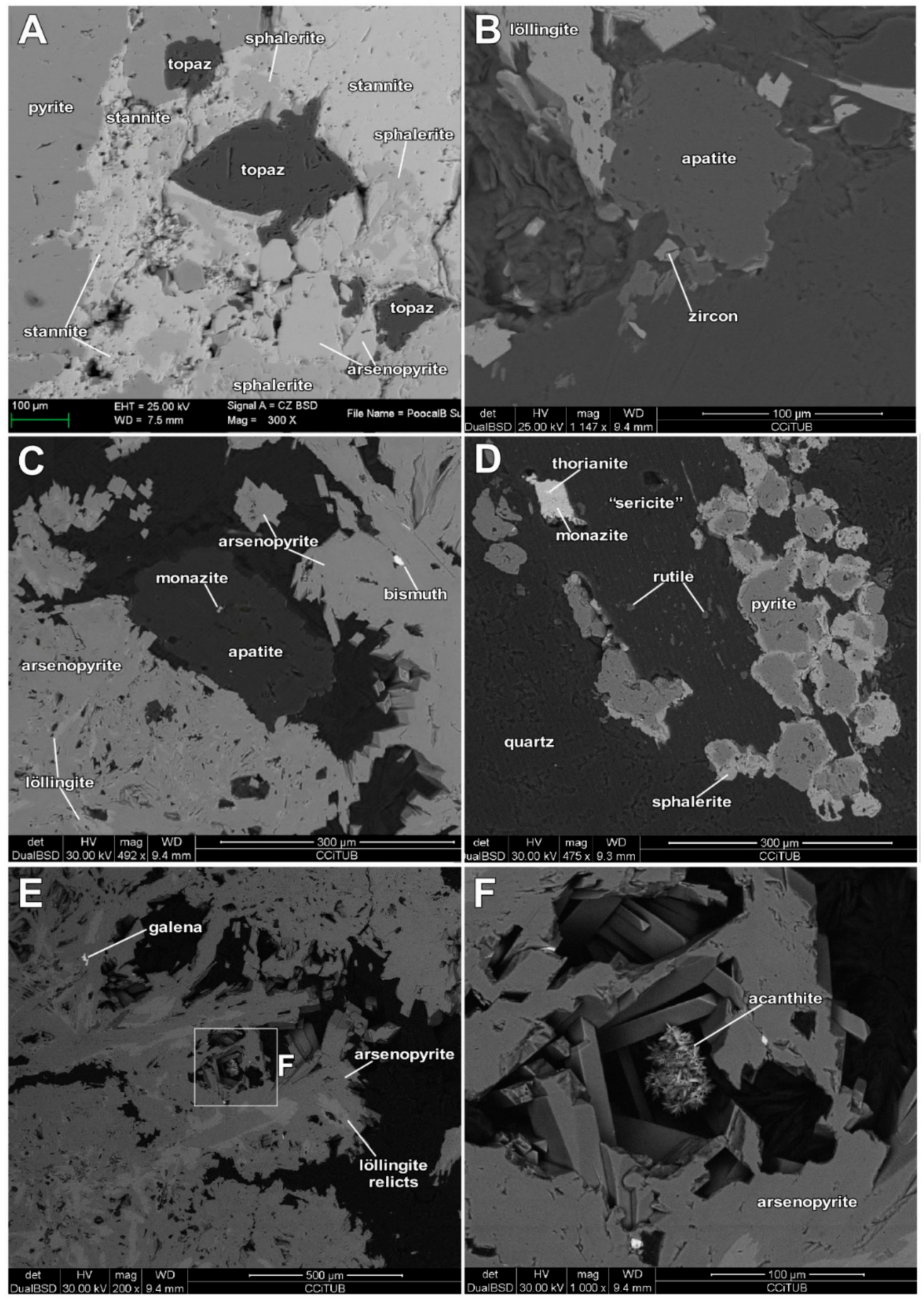

Figure 5. Back-scattered electron images of early mineralisation (Stage 1) in the Poopó deposit. (A) Early arsenopyrite followed by topaz and pyrite, and by a close association between sphalerite and stannite that formed reactively at the expense of pyrite; sample from the Calaveras section. (B) Apatite and zircon in close association with early löllingite. (C) Monazite enclosed in apatite in close association with löllingite, the latter having been almost entirely replaced by arsenopyrite. (D) Thorianite enclosed in monazite, in association with pyrite that was partly replaced by sphalerite. (E) Similar association to $C$, in which arsenopyrite and galena replaced löllingite, that remains as relicts. $(F)$ Inset from $E$ that shows late micro-aggregates of acanthite crystals in cavities; it is uncertain whether these formed before or after the replacement of löllingite by arsenopyrite. 


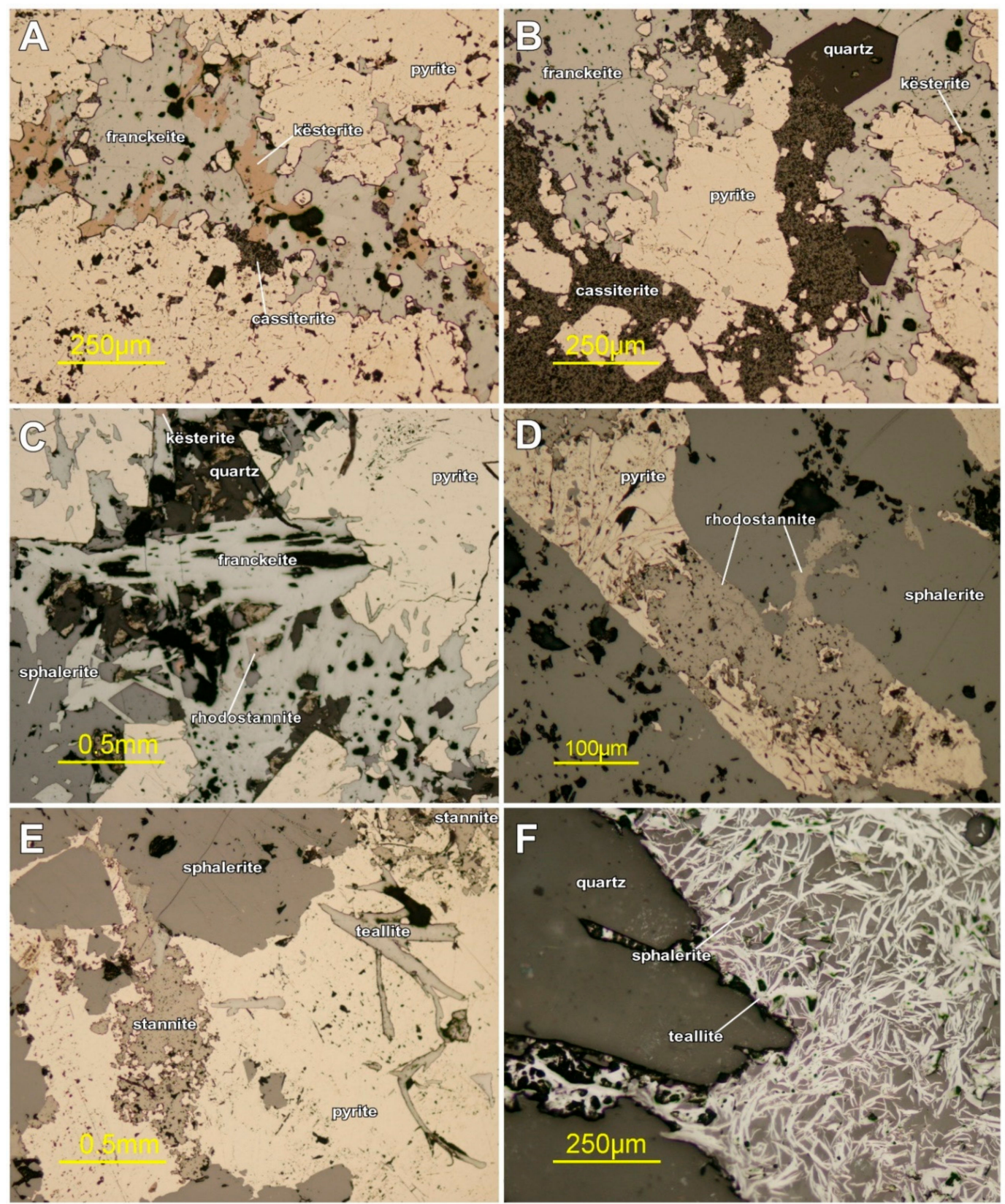

Figure 6. Polarised reflected light images of ore associations that are rich in tin minerals at the Poopó deposit. (A,B) Pyrite reactively followed by cassiterite ("needle tin"), passively followed by quartz, reactively followed by franckeite and these, in turn, by kësterite. (C) Pyrite reactively followed by franckeite + sphalerite, reactively followed by rhodostannite and kësterite. (D) Pyrite reactively followed by sphalerite, and reactively followed by rhodostannite. (E) Sphalerite reactively followed by pyrite, and by stannite + teallite. (F) Close association between sphalerite and teallite. 


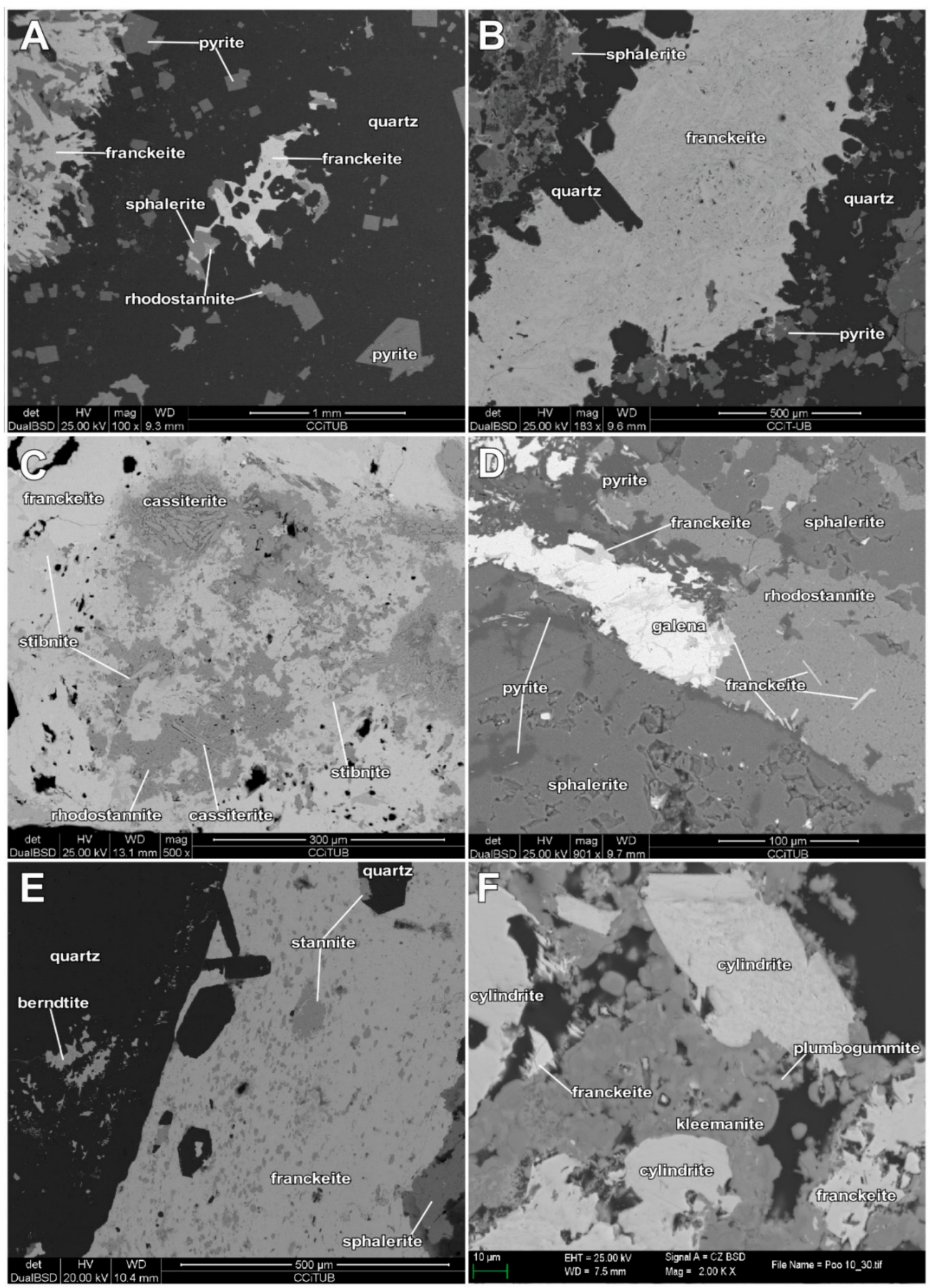

Figure 7. Back-scattered electron images of ore associations that are rich in tin minerals at the Poopó deposit. (A,B) Micro-cavities or geodes dominantly lined by franckeite; notice that sphalerite in B occurs earlier in the paragenetic sequence than in A. (C) Franckeite replaced by an assemblage of rhodostannite, cassiterite and stibnite. (D) Sphalerite replaced by pyrite and galena, and then by rhodostannite and franckeite. (E) Micro-cavities in quartz lined by bendtite, and banded mineralisation with mutual intergrowths of quartz, franckeite and stannite. (F) Cylindrite and franckeite followed by supergene kleemanite and plumbogummite. 



Figure 8. Back-scattered electron images of ore associations that are rich in lead and silver sulphosalts at the Poopó deposit. (A to C) Earlier sphalerite, pyrite and cassiterite associations postdated by jamesonite with later andorite (A), rhodostannite (B) or intergrown with terrywallaceite (C). (D) Acicular jamesonite crystals with later andorite lining the remaining cavity. (E) Close topaz + arsenopyrite association (similar to Figure 5A) followed by a close sphalerite + stannite association, and by canfieldite-lined micro-fractures; sample from the Calaveras section. (F) Andorite + pyrite that reactively followed sphalerite. 
Vein Minerals

The mineralogy determined in this study for the Poopó deposits is very complex, as over fifty species have been identified as part of the vein mineral associations, and their interrelationships can be rather intricate. "Simple" sulphides and arsenides in the Poopó deposits are sphalerite and wurtzite [ZnS], pyrite and marcasite $\left[\mathrm{FeS}_{2}\right]$, rhodostannite $\left[\mathrm{Cu}_{2} \mathrm{FeSn}_{3} \mathrm{~S}_{8}\right]$, stannite to kësterite $\left[\mathrm{Cu}_{2}(\mathrm{Zn}, \mathrm{Fe}) \mathrm{SnS} 4\right]$, herzenbergite $[\mathrm{SnS}]$, berndtite $\left[\mathrm{SnS}_{2}\right]$, galena $[\mathrm{PbS}]$, stibnite $\left[\mathrm{Sb}_{2} \mathrm{~S}_{3}\right]$, acanthite $\left[\mathrm{Ag}_{2} \mathrm{~S}\right]$, jalpaite $\left[\mathrm{Ag}_{3} \mathrm{CuS} 2\right]$, greenockite $[\mathrm{CdS}]$, bismuthinite $\left[\mathrm{Bi}_{2} \mathrm{~S}_{3}\right]$, "stibiobismuthinite" $\left[(\mathrm{Bi}, \mathrm{Sb})_{4} \mathrm{~S}_{7}\right]$, teallite $\left[\mathrm{PbSnS}_{2}\right]$, pyrrhotite $\left[\mathrm{Fe}_{1-\mathrm{x}} \mathrm{S}\right]$, cinnabar $[\mathrm{HgS}]$, arsenopyrite [FeAsS], and löllingite [FeAs$\left.s_{2}\right]$. Tin sulphosalts are cylindrite $\left[\mathrm{Pb}_{3} \mathrm{Sn}_{4} \mathrm{FeSb}_{2} \mathrm{~S}_{14}\right]$, franckeite $\left[\mathrm{Fe}^{2+}\left(\mathrm{Pb}, \mathrm{Sn}^{2+}\right)_{6} \mathrm{Sn}_{2}{ }^{4+} \mathrm{Sb}_{2} \mathrm{~S}_{14}\right]$, and "incaite" [(Pb,Ag) $\left.)_{4} \mathrm{Sn}_{4} \mathrm{FeSb}_{2} \mathrm{~S}_{15}\right](\mathrm{a}$ $\mathrm{Sn}^{2+}$-rich variety of franckeite). Lead, silver and copper sulphosalts are jamesonite $\left[\mathrm{Pb}_{4} \mathrm{FeSb}_{6} \mathrm{~S}_{14}\right]$, andorite $\left[\mathrm{PbAgSb}_{3} \mathrm{~S}_{6}\right]$, terrywallaceite $\left[\mathrm{AgPb}(\mathrm{Sb}, \mathrm{Bi})_{3} \mathrm{~S}_{6}\right]$, treasurite $\left[\mathrm{Ag}_{7} \mathrm{~Pb}_{6} \mathrm{Bi}_{15} \mathrm{~S}_{32}\right]$, tetrahedrite to tennantite $\left[(\mathrm{Cu}, \mathrm{Fe})_{12}(\mathrm{Sb}, \mathrm{As})_{4} \mathrm{~S}_{13}\right]$, proustite to pyrargyrite $\left[\mathrm{Ag}_{3}(\mathrm{As}, \mathrm{Sb}) \mathrm{S}_{3}\right]$, canfieldite $\left[\mathrm{Ag}_{8} \mathrm{SnS}_{6}\right]$, ramdohrite $\left[\mathrm{Ag}_{3} \mathrm{~Pb}_{6} \mathrm{Sb}_{11} \mathrm{~S}_{24}\right]$, and semseyite $\left[\mathrm{Pb}_{9} \mathrm{Sb}_{8} \mathrm{~S}_{21}\right]$. Besides minerals of the sulphides class, other minerals in the ore associations in the Poopó deposits are native bismuth [Bi], topaz $\left[\mathrm{Al}_{2}\left(\mathrm{SiO}_{4}\right)(\mathrm{F}, \mathrm{OH})_{2}\right]$, cassiterite $\left[\mathrm{SnO}_{2}\right]$, wolframite $\left[(\mathrm{Fe}, \mathrm{Mn}) \mathrm{WO}_{4}\right]$, apatite $\left[\mathrm{Ca}_{5}\left(\mathrm{PO}_{4}\right)_{3}\right]$, zircon $\left[\mathrm{ZrSiO} \mathrm{O}_{4}\right]$, monazite $\left[(\mathrm{Ce}, \mathrm{La}, \mathrm{Nd}, \mathrm{Th}) \mathrm{PO}_{4}\right]$, thorianite $\left[\mathrm{ThO}_{2}\right]$, adularia $\left[\mathrm{KAlSi}_{3} \mathrm{O}_{8}\right]$, siderite $\left[\mathrm{FeCO}_{3}\right]$, kleemanite $\left[\mathrm{ZnAl}_{2}\left(\mathrm{PO}_{4}\right)_{2}(\mathrm{OH})_{2} \cdot 3 \mathrm{H}_{2} \mathrm{O}\right]$, and plumbogummite $\left[\mathrm{PbAl}_{3}\left(\mathrm{PO}_{4}\right)_{2}(\mathrm{OH})_{5} \cdot \mathrm{H}_{2} \mathrm{O}\right]$. All these minerals are hypogene, with the exception of kleemanite and plumbogummite, which are considered as supergene minerals. Additional supergene minerals [25] are epsomite $\left[\mathrm{MgSO}_{4} \cdot 7 \mathrm{H}_{2} \mathrm{O}\right]$, kermesite $\left[\mathrm{Sb}_{2} \mathrm{~S}_{2} \mathrm{O}\right]$, and vivianite $\left[\mathrm{Fe}^{2+}{ }_{3}\left(\mathrm{PO}_{4}\right)_{2} \cdot 8 \mathrm{H}_{2} \mathrm{O}\right]$. Additional hypogene minerals [25] are argyrodite $\left[\mathrm{Ag}_{8} \mathrm{GeS}_{6}\right]$, zinkenite $\left[\mathrm{Pb}_{9} \mathrm{Sb}_{22} \mathrm{~S}_{42}\right]$, and baryte $\left[\mathrm{BaSO}_{4}\right]$. The interrelations among these minerals can be very complex, with either passive or reactive sequential precipitation (Figures 4-8).

Sphalerite constitutes the $60 \%$ (modal) of mineralisation, which makes of it the most abundant mineral altogether in the ore, and it occurs in various generations. It occurs generally as anhedral crystals intergrown with other minerals with very variable sizes (Figure 4C-E, Figure 5A, Figure 6C,F and Figure $8 \mathrm{~A}, \mathrm{~B}, \mathrm{E})$, and with dark colours, which is a common indicator of high $\mathrm{X}_{\mathrm{FeS}}$ values, as confirmed from EPMA analyses (see sections below). Sphalerite can be limitedly replaced by small amounts of fine-grained chalcopyrite, stannite or rhodostannite (Figures 5A and 6D,E) and pyrrhotite. Its polymorph wurtzite cannot be easily differentiated from sphalerite due to its colour, anhedral character, and the nearness of their main peaks in XRD spectra. However, wurtzite can be identified effectively when its euhedral terminations are visible in cavities.

Rhodostannite is the most abundant tin sulphide in the mineralisation as it accounts for $80 \%$ (modal) among such minerals. It occurs as heterogeneous aggregates of brownish to rosy (under transmitted light) anhedral crystals. Stannite and kësterite are polymorphs and each constitutes its own isomorphic series with iron-rich end-members, i.e., stannite-ferrostannite and kësterite-ferrokësterite, all of them within the stannite group of the sulphide class. Kësterite is generally richer in $\mathrm{Zn}$ than stannite and has low anisotropy, whereas stannite is richer in Fe than kësterite, strongly anisotropic, and distinctly twinned. Such characteristics allowed to determining that the most abundant mineral from this group in the Poopó deposit is stannite.

Cassiterite accounts for less than $10 \%$ (modal) of vein mineral assemblage, and constitutes a major mineral in the mineralisation. Its crystal quality and shape, and the shape of its aggregates are very variable, but it is common as interstitial crystals to sphalerite or as "needle tin", that is, heterogeneously distributed acicular crystals (Figure 6A,B). Topaz occurs as zoned euhedral crystals, as vein material (Figure 5A).

Galena, stibnite and acanthite are relatively scarce minerals in this deposit, as most of the lead, antimony and silver appear to be concentrated preferentially in sulphosalts rather than in "simple" sulphides. These minerals are commonly associated with suphosalts with similar cationic content, essentially Ag, Ag- $\mathrm{Pb}, \mathrm{Pb}$, and $\mathrm{Sn}-\mathrm{Ag}$ sulphosalts. Similarly, canfieldite occurs in association with $\mathrm{Sn}$ sulphides or Sn-Ag sulphosalts, generally in fractures as a late mineral (Figure 8E). Bismuthinite, a rare mineral in the deposit, is found as replacements after native bismuth. 
Löllingite is a trace mineral in the deposit as it only occurs as relict grains within replacive arsenopyrite. However, its pseudomorphosed crystals can be identified as prismatic, euhedral, and up to $1 \mathrm{~mm}$ long (Figure 5E,F). Arsenopyrite can be locally abundant in the deposit and it may occur in different generations as euhedral crystals up to $100 \mu \mathrm{m}$ in diameter, and found forming massive monomineralic aggregates. It is considered to be a relatively early mineral in each particular association (Figure 5) as is commonly crosscut by other minerals. The replacement of pyrrhotite by pyrite and marcasite occurred with the development of "bird's eyes" textures (Figure 4E). These minerals determine a löllingite $\rightarrow$ (reactive) arsenopyrite $\rightarrow$ (passive) pyrrhotite $\rightarrow$ (reactive) pyrite sequence that is characteristic of early stage 2 .

Cylindrite and franckeite are the most characteristic tin sulphosalts of the Poopó district (Figures 6 and 7), and are conspicuous to the point that cylindrite was first described in this locality [26]. Cylindrite is quite visible in hand specimens as radial aggregates of long cylindrical crystals in cavities. Franckeite is a common mineral in the Poopó deposits but rather rare in other localities. It occurs commonly as $>500 \mu \mathrm{m}$ wide tabular crystals in association with other minerals (especially cylindrite, sphalerite, rhodostannite, stannite and kësterite; Figures 6 and 7) or as massive aggregates. Both tin sulphosalts occur late in the mineral associations, typically lining micro-fractures (Figures 6 and 7).

Jamesonite is abundant in the paragenesis, and occurs as prismatic crystals up to $300 \mu \mathrm{m}$ long with well-developed shapes in cavities, but also as massive aggregates or lining micro-fractures (Figure 8). Andorite is another characteristic mineral in these deposits and can be locally abundant as elongated crystals or as massive aggregates lining cavities (Figure 8). Terrywallaceite is typically associated with jamesonite, even replacing it or intergrown with it (Figure 8C). The rest of the numerous sulphosalt species are relatively rare minerals and their space interrelations are less clear than the above.

Among phosphates, apatite and monazite are relatively rare in the mineralisation (Figure 5). Monazite is closely associated with (even rarer) thorianite. Kleemanite and plumbogummite occur as late minerals in the paragenetic sequence, likely as supergene products of $\mathrm{Zn}$ and $\mathrm{Pb}$ minerals (Figure 7F).

\subsection{Paragenetic Sequence}

Three stages of mineralisation can be characterised from this study (Figure 9), based in the interrelations of ore minerals, provided that no crosscutting relations between macroscopic structures were macroscopically observed: (1) an association dominated by quartz, pyrite, arsenopyrite, sphalerite and cassiterite (Zn-Sn stage), (2) an association of tin sulphides and sulphosalts (Sn stage), and (3) an association of antimony, lead and silver sulphosalts (Ag-Pb stage). As explained above, the character of the mineralisation was determined by periods of activity of the Poopó-Uyuni fault. Therefore, Stage 1 is essentially represented by breccias with fragments that vary in size ( $\mathrm{mm}$ - to $\mathrm{cm}$-sized) and shape (generally rounded). Pre-brecciation associations are mostly fine-grained, and coarsen in open cavities. This stage may consist of euhedral quartz, cassiterite and pyrite, and a later association in which sphalerite replaced pre-existing cassiterite. Stage 2 was preceded by some activity in the Poopó-Uyuni fault and is characterised by open-space lining textures (i.e., comb or cockade growth) in which most sulphides occur along with tin sulphosalts. As already noticed in previous work [27], stannite is relatively scarce and rhodostannite, cylindrite and franckeite were formed in its stead. Stage 3 has a replacing character with respect to previously formed minerals (especially those of Stage 2), and is dominated by jamesonite and concentrated silver minerals.

Besides such general behaviour, part of the mineralisation in the northern part of the district (the Calaveras section; Figure 2) contains topaz (Figure 5A), wolframite, bismuthinite, and apatite, with accessory monazite, zircon and thorianite (Figure 5B-D) as vein material in close association with sulphides, arsenides and sulphosalts. 


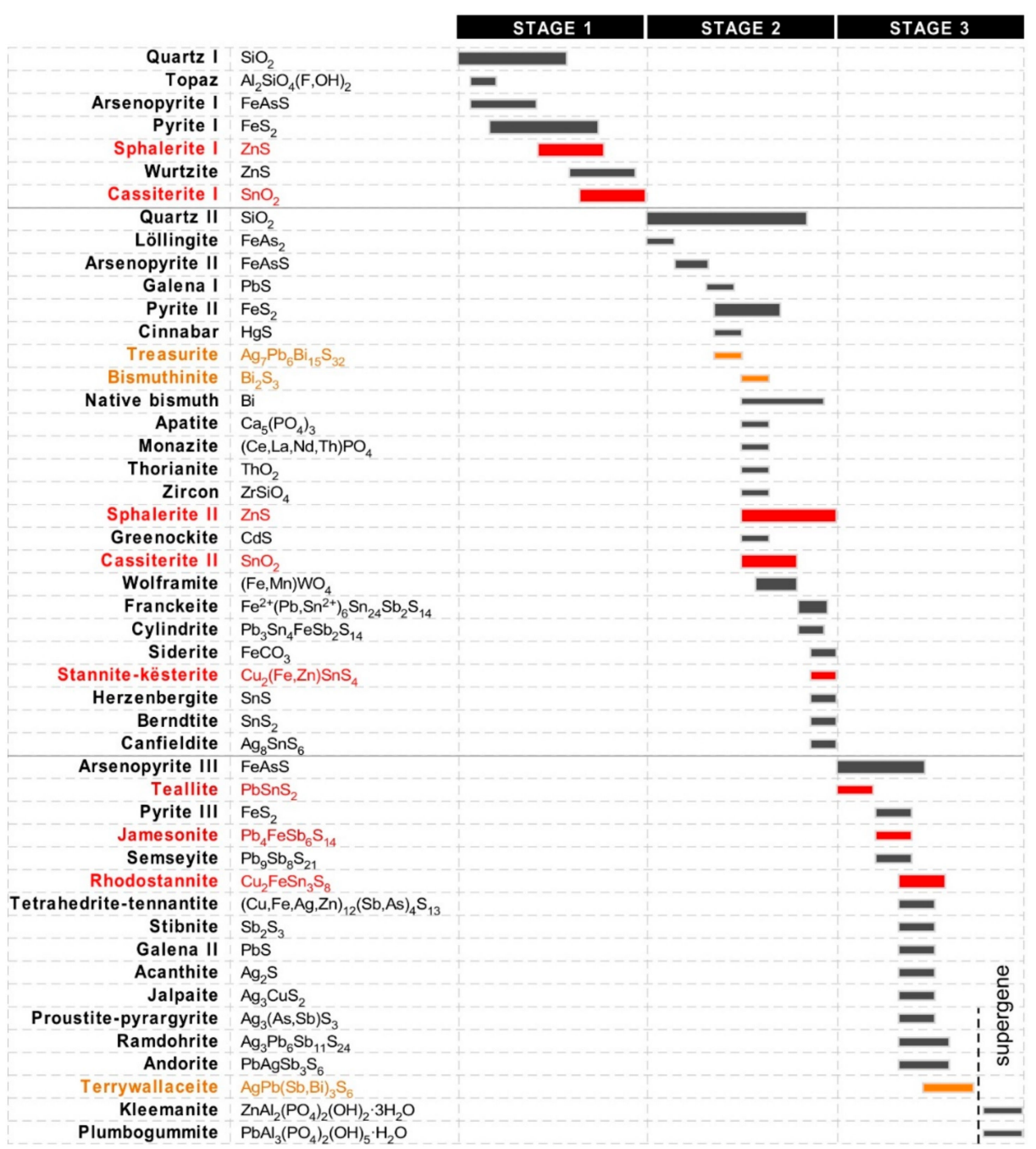

Figure 9. Paragenetic sequence obtained in this study for the Poopó deposit. Notice critical element-bearing minerals highlighted in red (most abundant or richer in those elements) and orange (less abundant or poorer in those elements).

\section{Mineral Chemistry}

The use of EPMA allowed to systematically characterising the elemental distribution in ore minerals (Table S1). Sphalerite in the Poopó deposit attains $\mathrm{X}_{\mathrm{FeS}}$ values up to 0.18 (18 wt.\%), high $\mathrm{Cd}$ (up to $1 \mathrm{wt} . \%$ ), and low In contents (up to $0.5 \mathrm{wt.} \%$ ). Fe and Ti contents in cassiterite are below 1 wt. $\%$, whereas Ta contents are about $0.2 \mathrm{wt} . \%$. Arsenopyrite crystals are strongly zoned due to their variable $\mathrm{Sb}$ contents (up to $5 \mathrm{wt} . \% \mathrm{Sb}$ ), whereas its $\mathrm{Co}$ and Ni contents rarely exceed $1 \mathrm{wt} . \%$. The As contents in arsenopyrite are systematically greater than those of $\mathrm{S}$, and amount between $28.9 \mathrm{wt} . \%$ and $31.8 \mathrm{wt} . \%$ As. In the absence of pyrite during the precipitation of arsenopyrite, which was formed as the replacement of löllingite, these compositions correspond to temperatures that range between $\sim 170{ }^{\circ} \mathrm{C}$ and $\sim 325^{\circ} \mathrm{C}$ (Figure 10).

Stannite is up to $0.45 \mathrm{wt} . \% \mathrm{Ag}$, and also rich in $\mathrm{Ge}, \mathrm{Se}, \mathrm{Cd}$ and $\mathrm{In}$, with contents that range between $0.13 \mathrm{wt} . \%$ and $0.47 \mathrm{wt} . \%$. Besides sphalerite and stannite, other minerals with relatively high cadmium contents are franckeite, rhodostannite, jamesonite, andorite and terrywallaceite, perhaps due to partial replacement of greenockite from Stage 2. Franckeite, cylindrite and rhodostannite can also be relatively rich in silver; rhodostannite may attain $4.6 \mathrm{wt} . \% \mathrm{Ag}$, thus nearing the stoichiometric composition of toyohaite $\left[\mathrm{Ag}_{2} \mathrm{FeSn}_{3} \mathrm{~S}_{8}\right]$. 


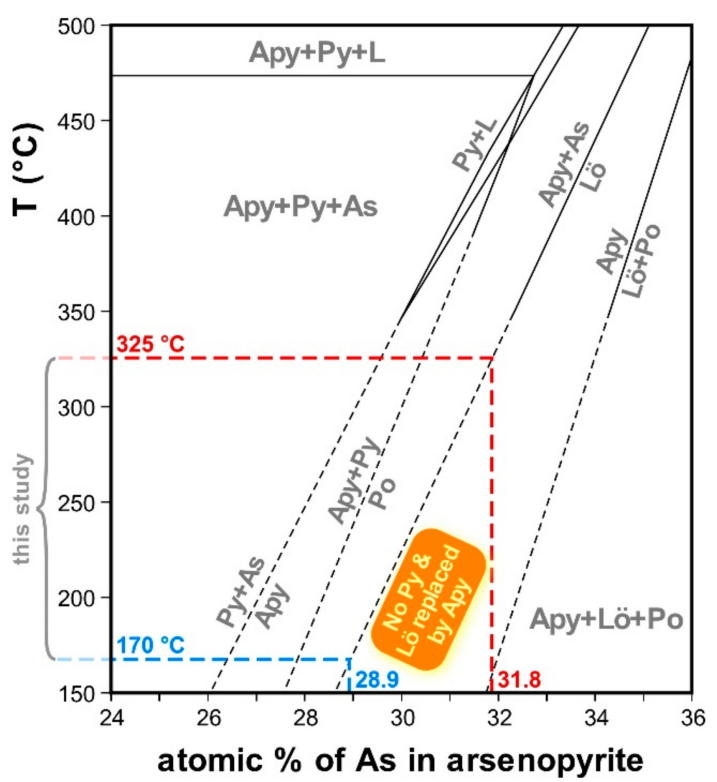

Figure 10. Arsenopyrite geothermometry based on the pseudobinary T-X diagram of Reference [28] for the Poopó deposits. The range of temperatures was obtained by using the EPMA analysed of arsenopyrite in Table S1, plotted against the arsenopyrite + arsenic/löllingite boundary considering (1) the absence of pyrite in association with arsenopyrite, (2) the sequence that determines that löllingite was replaced by arsenopyrite, and (3) pyrrhotite was passively precipitated on arsenopyrite, and then replaced by pyrite. The löllingite $\rightarrow$ arsenopyrite $\rightarrow$ pyrrhotite $\rightarrow$ pyrite sequence denotes an increasing availability of sulphur in the environment or a temperature rise (e.g., Figure 16 in Reference [5]). Key: Apy $=$ arsenopyrite, $\mathrm{As}=$ native arsenic, $\mathrm{L}=$ liquid, $\mathrm{Lö}=$ löllingite, $\mathrm{Po}=$ pyrrhotite, $\mathrm{Py}=$ pyrite.

As of EPMA analyses, relevant indium contents were found in franckeite, rhodostannite, sphalerite, cassiterite and stannite, but only traces of gallium were found. EPMA values and guidelines from References [29-33] allowed to selecting the most susceptible minerals to contain relevant amounts of strategic elements indium and gallium, which were considered to be sphalerite, cassiterite, stannite and rhodostannite. The most noticeable germanium contents were consistently obtained by means of EPMA in rhodostannite (up to $0.21 \mathrm{wt} . \% \mathrm{Ge}$ ) and franckeite (up to $0.16 \mathrm{wt} . \% \mathrm{Ge}$ ), and this element was also quantified in bismuthinite, terrywallaceite, jamesonite, stannite, treasurite, and in unidentified minerals (Table S1). Other strategic elements, such as tantalum, were also analysed in cassiterite, with contents averaging $0.2 \mathrm{wt} . \% \mathrm{Ta}$ (Table S1), which are comparable to those in other occurrences in the world with soundly determined magmatic origins [34-37].

LA-ICP-MS analyses yielded very variable contents in indium and gallium, by means of the quantification of ${ }^{115} \mathrm{In}$ and ${ }^{69} \mathrm{Ga}$ (Figure 11, Table 1 and Table S2). Such contents are up to 10,500 ppm In (>1 wt.\% In) and $1360 \mathrm{ppm} \mathrm{Ga} \mathrm{(>0.1} \mathrm{wt. \%} \mathrm{Ga)} \mathrm{in} \mathrm{sphalerite,} \mathrm{up} \mathrm{to} \mathrm{183,000} \mathrm{ppm} \mathrm{In} \mathrm{(18.3} \mathrm{wt. \%} \mathrm{In)}$ and $3060 \mathrm{ppm} \mathrm{Ga} \mathrm{(>0.3} \mathrm{wt. \%} \mathrm{Ga)} \mathrm{in} \mathrm{cassiterite,} \mathrm{up} \mathrm{to} \mathrm{11,100} \mathrm{ppm} \mathrm{In} \mathrm{(>1.1} \mathrm{wt.} \%$ In) and $3200 \mathrm{ppm}$ (>0.3 wt.\% Ga) Ga in stannite, up to 10,800 ppm In ( 1.1 wt.\% In) and 108 ppm Ga in teallite, and up to $6070 \mathrm{ppm}$ In (>0.6 wt.\% In) and $441 \mathrm{ppm} \mathrm{Ga}$ in rhodostannite. The two minerals with apparent higher contents in In (cassiterite and rhodostannite) are those with lower and more erratic contents in $\mathrm{Ga}$ (except in rhodostannite), whereas the mineral with the apparent lower contents in In (sphalerite) shows the higher contents in Ga (Figure 11). With the exception of the peak In and Ga contents in rhodostannite, such contents behave much alike those in teallite. 


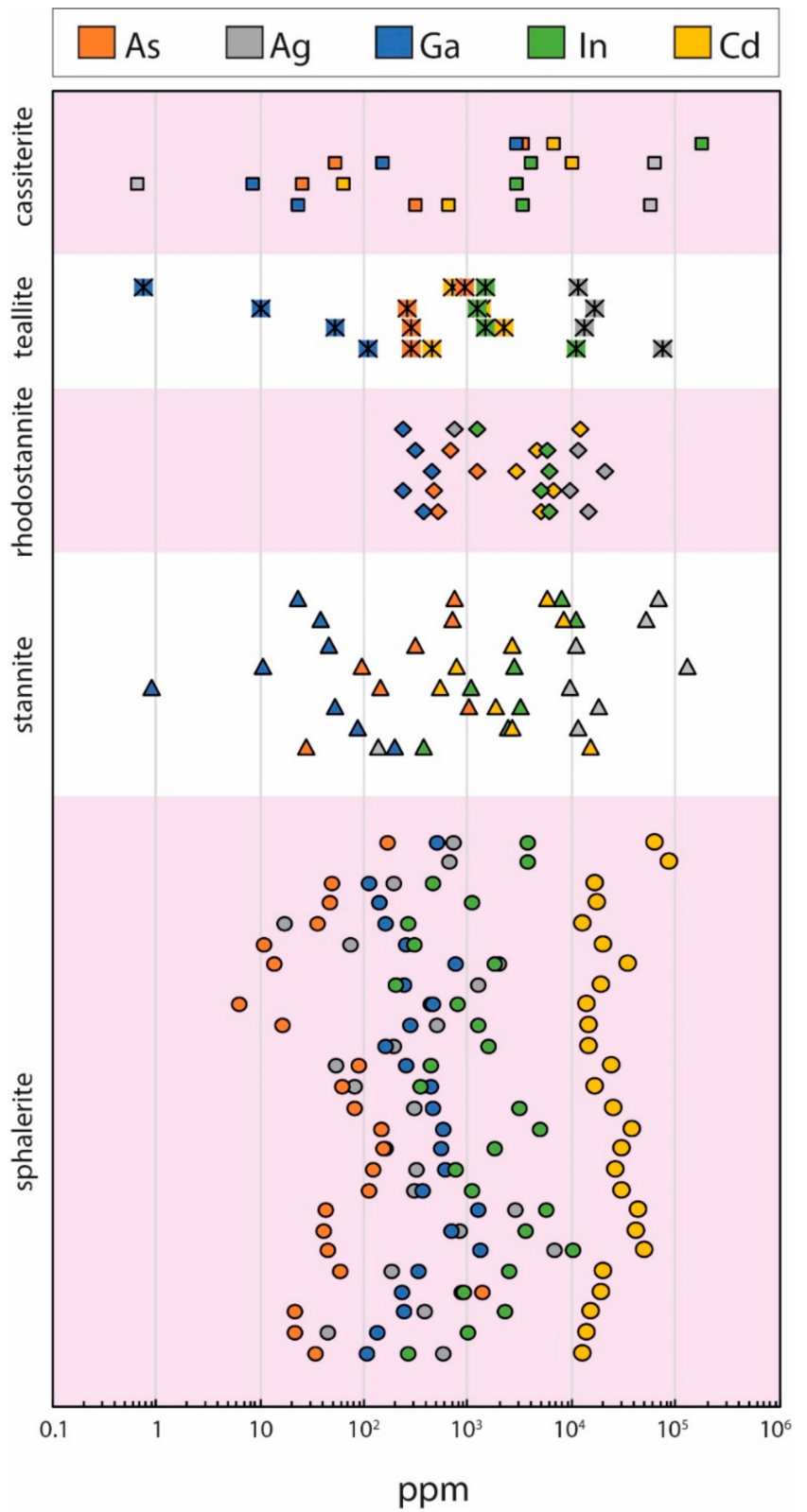

Figure 11. As, Ag, Ga, Sn, In and Cd contents in key minerals cassiterite, teallite, rhodostannite, stannite and sphalerite of the Poopó deposit as per LA-ICP-MS determinations. See data for critical elements In and Ga in Table 1 and for all elements in Table S2.

\section{Sulphur Isotopes}

Sulphur isotope determinations were carried out on 17 sulphide (sphalerite, galena, chacopyrite and pyrite) samples from the Poopó deposit. $\delta^{34} \mathrm{~S}_{\mathrm{VCDT}}$ values range between $-5.9 \%$ o and $-2.8 \%$ o altogether, and most values occur within a narrow range between -6 and $-4 \%$ o. $\delta^{34} \mathrm{~S}$ values range between $-5.4 \%$ ond $-3.4 \%$ in pyrite, between $-5.8 \%$ ond $-2.8 \%$ o in sphalerite, between $-4.8 \%$ ond $-4.2 \%$ in chalcopyrite, and $-5.9 \%$ in galena (Table 2 and Figure 12 ). 


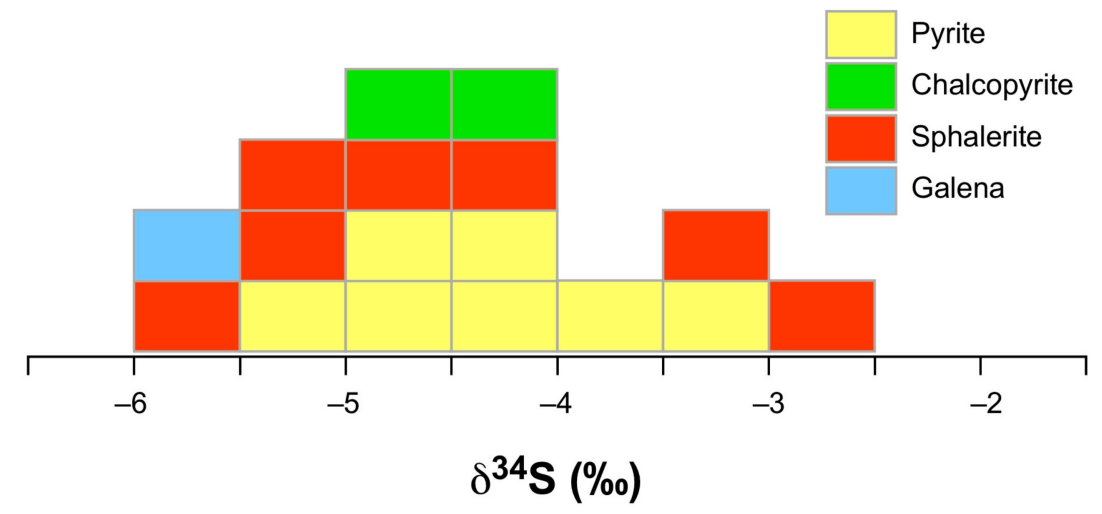

Figure 12. Histogram of the isotopic composition of sulphur in sulphides of the Poopó deposit, Bolivia. See data in Table 2.

\section{Discussion}

\subsection{Type of Deposit and Conditions of Formation}

The dominantly cataclastic character of textures in the Poopó deposit is due to the contemporaneity between the activity of the Poopó-Uyuni fault and the mineralisation processes in the associated veins (Figure $4 \mathrm{~A}-\mathrm{C}$ ). Such dominantly structural brecciation was cemented by new material of hydrothermal origin and could have controlled the polyphase and multi-episodic character of the mineralisation. Therefore, it is interpreted that the successive stages of mineralisation were closely associated with the activity of the Poopó-Uyuni fault. Based on the mineralogy determined in this study, we can endorse the interpretation that the Poopó deposits correspond to the Sn-rich low-sulphidation epithermal type, as formulated in Reference [8]. In particular, the abundance of löllingite pseudomorphs and arsenopyrite, and the occurrence of pyrrhotite (replaced by pyrite) place this deposit in the "classical" low-sulphidation field, as of Reference [37]. However, the occurrence of pyrophyllite indicates the entrainment of relatively high-temperature fluids of the high-sulphidation type, as typically occurs between the roots of epithermal deposits and porphyry-type deposits [38,39]. However, pyrophyllite can also be stable down to $100^{\circ} \mathrm{C}$ when water is supersaturated in silica, but still at low $\mathrm{pH}$ conditions [40]. The occurrence of topaz in epithermal deposits is not uncommon either, particularly in association with high to intermediate sulphidation fluids in the magmatic-epithermal transition or in deep hypogene advanced argillic alteration assemblages [41-44]. The low $\mathrm{pH}$ of fluids and high temperature that the occurrences of pyrophyllite and topaz entail is in apparent disagreement with the dominantly low sulphidation character of the mineralisation, which includes the occurrence of (A) the löllingite $\rightarrow$ arsenopyrite reactive sequence followed passively by the pyrrhotite $\rightarrow$ pyrite reactive sequence, (B) the occurrence of abundant $\mathrm{Ag}, \mathrm{Pb}$ or Sn sulphosalts, and (C) the occurrence of adularia and "sericite", either in the alteration assemblages or as vein material. Nevertheless, the occurrence of minerals that were formed at a relatively low $\mathrm{pH}$ in low- to intermediate-sulphidation epithermal deposits should not be shocking anymore [41]. In the Poopó case, it would be necessary to trace in detail the occurrence of pyrophyllite and topaz and their possible association with a temperature anomaly in the deposit. Such an anomaly would be most likely located on a preferential channelway for the upwelling of mineralising fluids along the Poopó-Uyuni fault, as is common in low to intermediate sulphidation deposits [41], and could constitute a form of telescoping. Detailed fluid inclusion and $\mathrm{O}$ and $\mathrm{H}$ stable isotope studies would be the ideal complement for such purpose. However, it is relevant to notice that the northern half of the mineralised structures, in which topaz occurs as vein material (Calaveras section, north of the Poopó village; Figure 2), lies beside a group of Miocene hypabyssal intrusive bodies with associated tourmalinisation (dacitic porphyries at the Cóndor Iquiña area; Figure 2) [21]. Such occurrence further highlights the likeliness for a proximal magmatic source for mineralising fluids, and thus it may spearhead the influx of magmatic fluids. This, in turn, suggests 
a possible elemental and mineralogical zonation of this deposit that would make an interesting topic for further studies.

Pyrophyllite and adularia do not occur in the same mineral associations and no temperature or $\mathrm{pH}$ evolution can thus be deduced from their occurrence. However, pyrophyllite and pyrite formed after early sphalerite in Stage 1 (sphalerite I in Figure 9), in reactive succession (Figure 3A-G), which implies a low-pH and high-fluorine incursion during the early ore stages, which evolved from relatively sulphur-deprived and low sulphidation fluids that originated the löllingite $\rightarrow$ arsenopyrite $\rightarrow$ pyrrhotite $\rightarrow$ pyrite sequence. The possible formation of pyrophyllite (thus, a low $\mathrm{pH}$ environment) in the midst of an overwhelmingly low-sulphidation environment may represent an excursion of low $\mathrm{pH}$ fluids similar to those explored in Reference [41].

The occurrence of adularia in epithermal deposits is commonly associated with boiling, whether in association with the precipitation of ore minerals or not [41]. The association between adularia and the formation of ore deposits is not clear at Poopó (Figure 3H), probably due to the scarcity of this mineral in comparison to other low-sulphidation epithermal deposits elsewhere. No other minerals or textural evidence that are suggestive of boiling have been found in the deposit, and thus the relevance of different mechanisms for ore formation can only be derived from further studies. Provided that the space distribution of adularia in each boiling event is anything but homogeneous [41], it would be possible to find this mineral abundantly in deeper portions of the deposit. Therefore, the known mineralisation at Poopó could correspond to the upward and lateral outflow carapace around the boiling areas (similar to Figure 11 in Reference [41]). Such possibilities will constitute starting hypotheses for future studies in this area.

The composition of arsenopyrite (with As contents greater than $\mathrm{S}$ contents) denotes low sulphur fugacity conditions during the precipitation of this mineral. However, arsenopyrite was predated by löllingite, which remains as relicts and was mostly consumed to form arsenopyrite (Figure 5E). The löllingite $\rightarrow$ arsenopyrite sequence indicates an increase in state of sulphidation, either by an increase in sulphur fugacity or a decrease in temperature. A similar evolution occurs next in the paragenetic sequence with the replacement of pyrrhotite by fine-grained pyrite and marcasite, as shown by the occurrence of "bird's eyes" textures (Figure 4E). Therefore, the löllingite $\rightarrow$ arsenopyrite $\rightarrow$ pyrrhotite $\rightarrow$ pyrite represents a sequence toward higher states of sulphidation within the low sulphidation field, at the beginning of Stage 2. Such an excursion toward higher states of sulphidation does not compare to the one described above for early Stage 1 and does not necessarily have a genetic meaning, but it remains a trend worth testing in further studies when it comes to the characterisation of the behaviour of mineralising fluids. Interestingly, it has been noted that (A) an increase in $\mathrm{pH}$ and $\mathrm{H}_{2} \mathrm{~S}$ activity, (B) a decrease in chlorine content (that is, a decrease in salinity of mineralising fluids), and (C) a decrease in temperature through conductive cooling have a role in increasing the primary indium saturation in mineralising fluids, particularly in the sphalerite-roquesite solid solution [45]. Otherwise, enrichment in indium may be produced by diffusion through earlier Fe-rich sphalerite, at decreasing $\mathrm{pH}$ and salinity, and increasing $S_{2}$ fugacity in mineralising fluids [45].

\subsection{Sources for Sulphur}

The sulphur isotope composition $\left(\delta^{34} \mathrm{~S}_{\mathrm{VCDT}}\right)$ of sulphides in Poopó ranges between $-5.9 \%$ and $-2.8 \%$, which is similar to those in several deposits of the central Andean tin belt, particularly those from the Santa Fe and Huanuni districts [46], in other tin deposits elsewhere [47], and in intermediateto low-sulphidation epithermal deposits in Cordilleran environments [48-50]. In such cases, hybrid sources for sulphur are suggested as most likely, in which part of the sulphur would come from magmatic sources (either from a direct contribution or by scavenging of sulphur from magmatic rocks) and another part would from sedimentary or metasedimentary sources. This idea would be supported by (A) the dominantly metasedimentary host rock assemblage in the Poopó deposits, and (B) the likeliness of magmatic-hydrothermal incursions into the mineralising system, as suggested by the occurrence (1) of pyrophyllite in deep hypogene alteration assemblages and (2) of topaz as 
vein material, besides the nearness of the deposits to possibly coetaneous hypabyssal and volcanic rocks (see section above). Another possibility is that the values obtained in this study account for purely magmatic sources for sulphur. This possibility can be sustained as long as parental magmas included a component of crustal assimilation; otherwise, sulphur would come from magmas that were generated after partial melting of sedimentary rocks. Such is precisely the case of the magmas associated with Cenozoic tin mineralisation of the Eastern Andean Cordillera, which resulted mostly from sediment melting in a thickened continental crust, and yield a distinctive peraluminous and reduced signature, thus belonging to the S-type, ilmenite-series [51-53]. The most likely magmatic source for sulphur and other geological elements for the mineralisation would come from the Late Miocene Morococala volcanic complex (Figure 1, [2]) and associated rocks. Both cases would result in significantly decreasing $\delta^{34} S$ values below the "typical" magmatic values around 0\%o [54]. Therefore, whether it is one possibility or the other, a magmatic source for sulphur is envisaged as the main contributor to the formation of sulphides in the Poopó deposit. However, part of the sulphur is likely to have been inherited from sedimentary or metasedimentary sources anyway.

\subsection{Distribution of Strategic Elements in the Deposit}

Besides the endowment in Sn and Ag of the Poopó epithermal deposit, the occurrence in it of strategic elements such as In, Ga and Ge deserves special attention in order to provide sound guidelines for exploration and mining endeavours in the area. No indium minerals like petrukite, roquesite, indite, laforetite, abramovite, or sakuraiite were found, and similarly with gallium and germanium. These elements were only found in traces within minerals in which they are not part of the stoichiometric norm. Therefore, indium occurs in noticeable contents in franckeite, rhodostannite, sphalerite, teallite, cassiterite and stannite as of EPMA and LA-ICP-MS analyses, and is up to $18 \mathrm{wt}$. $\%$ In in cassiterite, a major mineral in the deposit. High indium contents also occurred in stannite, sphalerite and teallite (up to $\sim 0.11$ wt. $\%$ In).

Gallium contents were determined to be up to $3060 \mathrm{ppm}$ Ga by means of LA-ICP-MS in cassiterite of Stage 3, although EPMA analyses were not apparently promising and also recorded the lowest obtained contents (Figure 11). However, the minerals in which the gallium content ranged less variably were sphalerite and rhodostannite (Figure 11), despite not having recorded peak contents in this element.

Although it was not found in this study, the occurrence of argyrodite [25] attests to the occurrence of germanium in the Poopó deposit. In this study, germanium contents hit a maximum in rhodostannite (up to 0.21 wt.\% Ge), although its interspecific distribution was wider than those of indium and gallium, as it is also a noticeable element in franckeite, bismuthinite, terrywallaceite, jamesonite, stannite-kësterite, treasurite, and some unidentified minerals.

Therefore, the key minerals with relevant contents in critical elements In, Ga and Ge in the Poopó deposit, based on their abundance in the deposit and compositions are rhodostannite, franckeite, cassiterite, stannite and, less importantly, sphalerite and jamesonite. Interestingly, such minerals occur all along the paragenetic sequence: rhodostannite, jamesonite, teallite and terrywallaceite in Stage 3, franckeite, stannite-kësterite and bismuthinite in Stage 2, and cassiterite and sphalerite in Stages 1 and 2. Furthermore, this study illustrates the need for evaluating the likeliness of high contents in strategic elements beyond "typical" bearers such as sphalerite or cassiterite.

\section{Conclusions}

The Sn- and Ag-rich polymetallic low-sulphidation epithermal deposits of Poopó in southwest Bolivia are circumscribed to the Bolivian Tin Belt and occur in a major regional boundary between the Andean Altiplano and the Eastern Andes Cordillera. Such boundary is represented by the Poopó-Uyuni fault, which constitutes the main mineralised structure in these deposits. It is likely that the formation of these deposits is linked to the activity of the Late Miocene Morococala volcanic complex. 
This study represents the first systematic characterisation to be made available about the Poopó deposits. The morphology of these deposits, their mineralogical characteristics, interrelations and evolution of alteration and ore associations allow us to endorse earlier characterisations of the Poopó deposits as a Sn- and Ag-rich low-sulphidation epithermal deposit. However, despite such endowment, these deposits may bear a major potential in strategic elements.

The studied deposits display very complex mineralogy and interrelations among the constituting minerals, which can be grouped into three consecutive stages of mineralisation. Stage 1 is described as a Zn-rich stage that includes the localised occurrence of topaz and pyrophyllite. Stage 2 is described as a $\mathrm{Sn}$-rich stage with tin sulphides and sulphosalts. Stage 3 is described as an Ag-Pb-rich stage with numerous sulphosalts of either or both metals. Both in Stages 1 and 2 the early minerals draw mineralogical sequences towards increasing states of sulphidation in ore associations (arsenopyrite to pyrite, or löllingite to arsenopyrite to pyrrhotite to pyrite).

The occurrences of pyrophyllite (in the alteration assemblage) and topaz (vein mineral association in Stage 1) stand out as indicators of low $\mathrm{pH}$ fluids at relatively high temperatures (high sulphidation) as mineralising fluids, although the Poopó deposits and the mineral associations contained in them are mostly circumscribed to the low-sulphidation type among epithermal deposits. Fluids associated with the deposition of pyrophyllite and topaz may have spearheaded the input of magmatic fluids through long-lasting preferential channelways for the ascent of hydrothermal fluids, which is a possibility that calls for attention in further studies.

The range of variation of $\delta^{34} \mathrm{~S}_{\mathrm{VCDT}}$ values in sulphides of the Poopó deposit suggests either mixed magmatic and sedimentary or metasedimentary sources for sulphur, or dominant magmatic sources after magmas that underwent significant crustal assimilation or, plainly, S-type magmas.

Strategic elements In, Ga and Ge (as of EPMA and LA-ICP-MS determinations) occur in noticeable amounts in several minerals of the Poopó deposits, among which rhodostannite, franckeite, cassiterite, stannite-kësterite, teallite (all of them tin minerals), sphalerite and jamesonite are major contributors due to both their abundance along the paragenetic sequence and their contents in such metals. Less importantly, bismuthinite, terrywallaceite and treasurite also have significant Ge contents. Rhodostannite and jamesonite (plus terrywallaceite) occur in Stage 3, franckeite and stannite-kësterite (plus bismuthinite) in Stage 2, and cassiterite and sphalerite in Stages 1 and 2; therefore, minerals with affinity for In, Ga and Ge occur through the entire paragenetic sequence.

Supplementary Materials: The following are available online at http://www.mdpi.com/2075-163X/9/8/472/s1, Table S1: EMPA. Table S2: ICP-MS.

Author Contributions: Conceptualization: J.-C.M., L.T., A.C., O.R.A.-B., P.A.; fieldwork: B.T., J.-C.M., L.T., D.A., A.J.-F.; methodology: B.T., J.-C.M., L.T., M.C.-O., D.A., M.C., E.T., P.A.; writing-original draft preparation: B.T., A.C.; writing-review and editing: A.C., J.-C.M., L.T., M.C.-O.

Funding: This study benefitted from the budged granted by the Generalitat de Catalunya (Autonomous Government of Catalonia) to the Consolidated Research Group SGR 444, the AECID project A3/042750/11, CCD project 2015-U008, and the Peruvian CONCYTEC-FONDECYT-World Bank project 107-2018. Additional funding was provided by the ARC Centre of Excellence for Core to Crust Fluid Systems (CE110001017), as well as by the Fundació Pedro Pons (UB), and by the Instituto de Geología (UNAM) by means of its yearly personal budget allocation. Part of the analytical data were obtained using instrumentation funded by DEST Systemic Infrastructure Grants, ARC LIEF, NCRIS/AuScope, industry partners and Macquarie University.

Acknowledgments: The National Federation of Mining Cooperatives of Bolivia (FENCOMIN) gave permission to the authors to access the studied mines and to perform the necessary sampling; all individuals from FENCOMIN, Juan Elvys Trujillo from the Universidad Técnica de Oruro, and local miners are cordially thanked for their kind and efficient help. Technical assistance was kindly provided by Xavier Alcobé, Maria Barba (XRD), Eva Prats, Aránzazu Villuendas (SEM-EDS), Xavier Llovet (EPMA), all of them at the Centres Científics i Tecnologics of the Universitat de Barcelona. The authors would like to acknowledge William L. Griffin and Suzanne Y. O'Reilly for their scientific insight, and William Powell, Yoann Gréau, Rosanna Murphy, Olivier Alard and Sarah Gain for their help with the LA-ICP-MS analyses at the GAU (Macquarie University). This is contribution 1374 from the ARC Centre of Excellence for Core to Crust Fluid Systems (http://www.ccfs.mq.edu.au) and 1326 in the GEMOC Key Centre (http://www.gemoc.mq.edu.au).

Conflicts of Interest: To the knowledge of the authors, no conflict of interest whatsoever exist between them and any other individuals with regard to the contents of this paper. The funders had no role in the design of the study, 
in the collection, analyses, or interpretation of data, in the writing of the manuscript, or in the decision to publish the results.

\section{References}

1. Turneaure, F.S. The Bolivian tin-silver province. Econ. Geol. 1971, 66, 215-225. [CrossRef]

2. Lehmann, B.; Ishihara, S.; Michel, H.; Miller, J.; Rapela, C.; Sanchez, A.; Tistl, M.; Winkelmann, L. The Bolivian tin province and regional tin distribution in the central Andes: A reassessment. Econ. Geol. 1990, 85, 1044-1058. [CrossRef]

3. Mlynarczyk, M.S.J.; Williams-Jones, A.E. The role of collisional tectonics in the metallogeny of the Central Andean tin belt. Earth Plan. Sci. Lett. 2005, 240, 656-667. [CrossRef]

4. Ishihara, S.; Murakami, H.; Marquez-Zavalia, M.F. Inferred indium resources of the Bolivian tin-polymetallic deposits. Resour. Geol. 2011, 61, 174-191. [CrossRef]

5. Torró, L.; Melgarejo, J.C.; Gemmrich, L.; Mollinedo, D.; Cazorla, M.; Martínez, Á.; Pujol-Solà, N.; Farré de Pablo, J.; Camprubí, A.; Artiaga, D.; et al. Spatial and temporal controls on the distribution of indium in xenothermal vein deposits: The Huari Huari district, Potosí, Bolivia. Minerals 2019, 9, 304. [CrossRef]

6. European Commission. Critical Raw Materials. Available online: https://ec.europa.eu/growth/sectors/rawmaterials/specific-interest/critical_en (accessed on 1 April 2019).

7. SERGEOTECMIN. Mapa Geológico de Bolivia, Escala 1:1.000.000; SERGEOTECMIN: La Paz, Bolivia, 2001.

8. Panteleyev, A. Epithermal Au-Ag: Low Sulphidation. In Selected British Columbia Mineral Deposit Profiles, Vol. 2-Metallic Deposits; Lefebure, D.V., Hõy, T., Eds.; British Columbia Ministry of Employment and Investment: Vancouver, BC, Canada, 1996; pp. 45-48.

9. Ahlfeld, F.; Schneider-Scherbina, A. Los yacimientos minerales y de hidrocarburos de Bolivia. Bol. Dept. Nac. Geol. La Paz 1964, 5, 1-388.

10. Jelsma, H.A.; de Wit, M.J.; Thiart, C.; Dirks, P.H.G.M.; Viola, G.; Basson, I.J.; Anckar, E. Preferential distribution along transcontinental corridors of kimberlites and related rocks of Southern Africa. South. Af. J. Geol. 2004, 107, 301-324. [CrossRef]

11. Nieto-Samaniego, A.F.; Alaniz-Álvarez, S.A.; Camprubí, A. The Central Mesa of México: Stratigraphy, structure and tectonic evolution during the Cenozoic. In Geology of México: Celebrating the Centenary of the Geological Society of México; Alaniz-Álvarez, S.A., Nieto-Samaniego, A.F., Eds.; The Geological Society of America: Boulder, CO, USA, 2007; Volume 422, pp. 41-70.

12. Gibson, G.M.; Meixner, A.J.; Withnall, I.W.; Korsch, R.J.; Hutton, L.J.; Jones, L.E.A.; Holzschuh, J.; Costelloe, R.D.; Henson, P.A.; Saygin, E. Basin architecture and evolution in the Mount Isa mineral province, northern Australia: Constraints from deep seismic reflection profiling and implications for ore genesis. Ore Geol. Rev. 2016, 76, 414-441. [CrossRef]

13. Deng, J.; Yang, L.Q.; Li, R.H.; Groves, D.I.; Santosh, M.; Wang, Z.L.; Sai, S.X.; Wang, S.R. Regional structural control on the distribution of world-class gold deposits: An overview from the Giant Jiaodong Gold Province, China. Geol. J. 2019, 54, 378-391. [CrossRef]

14. Sempere, T.; Hérail, G.; Oller, J.; Bonhomme, M.G. Late Oligocene-Early Miocene major tectonic crisis and related basins in Bolivia. Geology 1990, 18, 946-949. [CrossRef]

15. Sempere, T. Phanerozoic Evolution of Bolivia and Adjacent Regions; American Association of Petroleum Geologists (AAPG) Memoir: Tulsa, OK, USA, 1995; Volume 62, pp. 207-230.

16. McQuarrie, N. The kinematic history of the central Andean fold-thrust belt, Bolivia: Implications for building a high plateau. Bull. Geol. Soc. Am. 2002, 114, 950-963. [CrossRef]

17. McQuarrie, N.; DeCelles, P.G. Geometry and structural evolution of the Central Andean backthrust belt, Bolivia. Tectonics 2001, 20, 669-692. [CrossRef]

18. Eichelberger, N.; McQuarrie, N.; Ryan, J.; Karimi, B.; Beck, S.; Zandt, G. Evolution of crustal thickening in the central Andes Bolivia. Earth Plan. Sci. Lett. 2015, 426, 191-203. [CrossRef]

19. Ramos, V.A.; Aleman, A. Tectonic evolution of the Andes. In Tectonic Evolution of South America, Proceedings of 31st International Geological Congress, Rio de Janeiro, Brazil, 6-17 August 2000; Cordani, U.G., Milani, E.J., Thomaz Filho, A., Campos, D.A., Eds.; Brazilian Academy of Science-Departamento Nacional de Produção Mineral: Rio de Janeiro, Brazil, 2000; pp. 635-685. 
20. Lamb, S.; Hoke, L. Origin of the high plateau in the central Andes, Bolivia, South America. Tectonics 1997, 16, 623-649. [CrossRef]

21. Heuschmidt, B.; Bellot de la Torre, J.; Miranda Angles, V.; Claure Zapata, M. Las áreas prospectivas de Bolivia para yacimientos metalíferos. Boletín Serv. Nac. Geol. Min. 2002, 30, 154.

22. Jochum, K.P.; Weis, U.; Stoll, B.; Kuzmin, D.; Yang, Q.; Raczek, I.; Jacob, D.E.; Stracke, A.; Birbaum, K.; Frick, D.A.; et al. Determination of reference values for NIST SRM 610-617 glasses following ISO guidelines. Geostand. Geoanal. Res. 2011, 35, 397-429. [CrossRef]

23. Van Achterbergh, E.; Ryan, C.G.; Jackson, S.E.; Griffin, W.L. Data reduction software for LA-ICP-MS: Appendix. In Laser Ablation-ICP-Mass Spectrometry in the Earth Sciences: Principles and Applications; Sylvester, P.J., Ed.; Mineralogical Association of Canada: St. Johns, NL, Canada, 2001; Volume 29, pp. 239-243.

24. Griffin, W.L.; Powell, W.J.; Pearson, N.; O’Reilly, S.Y. GLITTER: Data reduction software for laser ablation ICP-MS. In Laser Ablation-ICP-MS in the Earth Sciences; Sylvester, P.J., Ed.; Mineralogical Association of Canada: St. Johns, NL, Canada, 2008; Volume 37, pp. 204-207.

25. Mindat.org. Poopó town, Poopó Province, Oruro, Bolivia. Available online: https://www.mindat.org/loc-350. html (accessed on 2 April 2019).

26. Frenzel, A. Über den Kylindrit. N. Jb. Miner. Geol. Paläont. 1893, 2, 125-128.

27. Kelly, W.C.; Turneaure, F.S. Mineralogy, paragenesis and geothermometry of the tin and tungsten deposits of the eastern Andes, Bolivia. Econ. Geol. 1970, 65, 609-680. [CrossRef]

28. Kretschmar, U.; Scott, S.D. Phase relations involving arsenopyrite in the system Fe-As-S and their application. Can. Mineral. 1976, 14, 364-386.

29. Andersen, J.C.Ø.; Stickland, R.J.; Rollinson, G.K.; Shail, R.K. Indium mineralisation in SW England: Host parageneses and mineralogical relations. Ore Geol. Rev. 2016, 78, 213-238. [CrossRef]

30. Sahlström, F.; Arribas, A.; Dirks, P.; Corral, I.; Chang, Z. Mineralogical distribution of germanium, gallium and indium at the Mt Carlton high-sulfidation epithermal deposit, NE Australia, and comparison with similar deposits worldwide. Minerals 2017, 7, 213. [CrossRef]

31. Liu, J.; Rong, Y.; Zhang, S.; Liu, Z.; Chen, W. Indium mineralization in the Xianghualing Sn-polymetallic orefield in southern Hunan, Southern China. Minerals 2017, 7, 173. [CrossRef]

32. Lerouge, C.; Gloaguen, E.; Wille, G.; Bailly, L. Distribution of In and other rare metals in cassiterite and associated minerals in $\mathrm{Sn} \pm \mathrm{W}$ ore deposits of the western Variscan Belt. Eur. J. Mineral. 2017, 29, 739-753. [CrossRef]

33. Murakami, H.; Ishihara, S. Trace elements of Indium-bearing sphalerite from tin-polymetallic deposits in Bolivia, China and Japan: A femto-second LA-ICPMS study. Ore Geol. Rev. 2013, 53, 223-243. [CrossRef]

34. Costi, H.T.; Coimbra Horbe, A.M.; Munhoz Krás Borges, R.; Dall'Agnol, R.; Sighnolfi, G. Mineral chemistry of cassiterites from Pitinga province, Amazonian, Craton, Brazil. Rev. Bras. Geoc. 2000, 30, 775-782. [CrossRef]

35. Melcher, F.; Graupner, T.; Gäbler, H.E.; Sitnikova, M.; Oberthür, T.; Gerdes, A.; Badanina, E.; Chudy, T. Mineralogical and chemical evolution of tantalum-(niobium-tin) mineralisation in pegmatites and granites. Part 2: Worldwide examples (excluding Africa) and an overview of global metallogenetic patterns. Ore Geol. Rev. 2017, 89, 946-987. [CrossRef]

36. Wille, G.; Lerouge, C.; Schmidt, U. A multimodal microcharacterisation of trace-element zonation and crystallographic orientation in natural cassiterite by combining cathodoluminescence, EBSD, EPMA and contribution of confocal Raman-in-SEM imaging. J. Microsc. 2018, 270, 309-317. [CrossRef]

37. Einaudi, M.T.; Hedenquist, J.W.; Inan, E.E. Sulfidation state of fluids in active and extinct hydrothermal systems: Transitions from porphyry to epithermal environments. Soc. Econ. Geol. Spec. Publ. 2003, 10, 285-313.

38. Teal, L.; Benavides, A. History and geologic overview of the Yanacocha mining district, Cajamarca, Peru. Econ. Geol. 2010, 105, 1173-1190. [CrossRef]

39. Hedenquist, J.W.; Taran, Y.A. Modeling the formation of advanced argillic lithocaps: Volcanic vapor condensation above porphyry intrusions. Econ. Geol. 2013, 108, 1523-1540. [CrossRef]

40. Hemley, J.J.; Montoya, J.W.; Marinenko, J.W.; Luce, R.W. Equilibria in the system $\mathrm{Al}_{2} \mathrm{O}_{3}-\mathrm{SiO}_{2}-\mathrm{H}_{2} \mathrm{O}$ and some implications for alteration/mineralization process. Econ. Geol. 1980, 75, 210-228. [CrossRef] 
41. Camprubí, A.; Albinson, T. Epithermal deposits in México-an update of current knowledge, and an empirical reclassification. In Geology of México: Celebrating the Centenary of the Geological Society of México; Alaniz-Álvarez, S.A., Nieto-Samaniego, A.F., Eds.; The Geological Society of America: Boulder, CO, USA, 2007; Volume 422, pp. 377-415.

42. Voudouris, P.C. Hydrothermal corundum, topaz, diaspore and alunite supergroup minerals in the advanced argillic alteration lithocap of the Kassiteres-Sapes porphyry-epithermal system, western Thrace, Greece. Neues Jahrb. Miner. Abh. 2014, 191, 117-136. [CrossRef]

43. Andressa, T.; Crósta, A.P.; Toledo, C.L.B.; Silva, A.M. Unveiling the hydrothermal mineralogy of the Chapi Chiara gold prospect, Peru, through reflectance spectroscopy, geochemical and petrographic data. Ore Geol. Rev. 2015, 64, 299-315.

44. Chambefort, I.; Lewis, B.; Simpson, M.P.; Bignall, G.; Rae, A.J.; Ganefianto, N. Ngatamariki geothermal system: Magmatic to epithermal transition in the Taupo volcanic zone, New Zealand. Econ. Geol. 2017, 112, 319-346. [CrossRef]

45. Schwarz-Schampera, U.; Herzig, P.M. Indium. Geology, Mineralogy, and Economics; Springer: Berlin, Germany, 2002.

46. Sugaki, A.; Ueno, H.; Hayashi, K. Sulfur isotope reconnaissance of Bolivian hydrothermal deposits. Min. Geol. 1990, 40, 299-312.

47. Xiong, Y.Q.; Shao, Y.J.; Mao, J.W.; Wu, S.C.; Zheng, M.H. The polymetallic magmatic-hydrothermal Xiangdong and Dalong systems in the $\mathrm{W}-\mathrm{Sn}-\mathrm{Cu}-\mathrm{Pb}-\mathrm{Zn}-\mathrm{Ag}$ Dengfuxian orefield, SE China: Constraints from geology, fluid inclusions, $\mathrm{H}-\mathrm{O}-\mathrm{S}-\mathrm{Pb}$ isotopes, and sphalerite $\mathrm{Rb}-\mathrm{Sr}$ geochronology. Miner. Depos. 2019. [CrossRef]

48. Camprubí, A.; Cardellach, E.; Canals, À.; Lucchini, R. The La Guitarra Ag-Au low sulfidation epithermal deposit, Temascaltepec district, Mexico: Fluid inclusion and stable isotope data. In New Mines and Discoveries in Mexico and Central America; Albinson, T., Nelson, C.E., Eds.; Society of Economic Geologists Special Publication: Littleton, CO, USA, 2001; Volume 8, pp. 159-185.

49. Camprubí, A.; González-Partida, E.; Torres-Tafolla, E. Fluid inclusion and stable isotope study of the Cobre-Babilonia polymetallic epithermal vein system, Taxco district, Guerrero, Mexico. J. Geochem. Explor. 2006, 89, 33-38. [CrossRef]

50. Mango, H.; Arehart, G.; Oreskes, N.; Zantop, H. Origin of epithermal Ag- $\mathrm{Au}-\mathrm{Cu}-\mathrm{Pb}-\mathrm{Zn}$ mineralization in Guanajuato, Mexico. Miner. Depos. 2014, 49, 119-143. [CrossRef]

51. Ishihara, S. The granitoid series and mineralization. Econ. Geol. 1981, 75, 458-484.

52. Morgan, G.B., IV; London, D.; Luedke, R.G. Petrochemistry of Late Miocene perluminous silicic volcanic rocks from the Morococala field, Bolivia. J. Pet. 1998, 4, 601-632. [CrossRef]

53. Lehmann, B.; Dietrich, A.; Heinhorst, J.; Metrich, N.; Mosbah, M.; Palacios, C.; Schneider, H.J.; Wallianos, A.; Webster, J.; Winkelmann, L. Boron in the Bolivian tin belt. Miner. Depos. 2000, 35, 223-232. [CrossRef]

54. Seal, I.R. Sulfur isotope geochemistry of sulfide minerals. Rev. Miner. Geochem. 2006, 61, 633-677. [CrossRef] 